NBER WORKING PAPER SERIES

\title{
RETIREMENT SECURITY IN AN AGING SOCIETY
}

\author{
James M. Poterba \\ Working Paper 19930 \\ http://www.nber.org/papers/w19930 \\ NATIONAL BUREAU OF ECONOMIC RESEARCH \\ 1050 Massachusetts Avenue \\ Cambridge, MA 02138 \\ February 2014
}

I am very grateful to Scott Nelson, Bryan Perry, and Ben Sprung-Keyser for outstanding research assistance, and to my long-time collaborators in the study of retirement saving, Steven Venti and David Wise, for all our work together. I thank Jeffrey Brown, Michael Hurd, David Johnson, Olivia Mitchell, William Nordhaus, Susann Rohwedder, Lawrence Summers, Steven Utkus, and the members of the National Research Council Committee on the Long-Run Macroeconomic Effects of the Aging U.S. Population for helpful discussions. My research on retirement saving over the last two decades has been supported by the National Institute of Aging and the National Science Foundation. I am a trustee of CREF and the TIAA-CREF mutual funds, providers of retirement saving products, and I have received compensation for presentations at conferences organized by the Investment Company Institute. The views expressed herein are those of the author and do not necessarily reflect the views of the National Bureau of Economic Research.

NBER working papers are circulated for discussion and comment purposes. They have not been peerreviewed or been subject to the review by the NBER Board of Directors that accompanies official NBER publications.

(C) 2014 by James M. Poterba. All rights reserved. Short sections of text, not to exceed two paragraphs, may be quoted without explicit permission provided that full credit, including $\bigcirc$ notice, is given to the source. 
Retirement Security in an Aging Society

James M. Poterba

NBER Working Paper No. 19930

February 2014

JEL No. E21,G11,H55,J14

\begin{abstract}
$\underline{\text { ABSTRACT }}$
The share of the U.S. population over the age of 65 was 8.1 percent in 1950, 12.4 percent in 2000, and is projected to reach 20.9 percent by 2050 . The percent over 85 is projected to more than double from current levels, reaching 4.2 percent by mid-century. The aging of the U.S. population makes issues of retirement security increasingly important.

Elderly individuals exhibit wide disparities in their sources of income. For those in the bottom half of the income distribution, Social Security is the most important source of support; program changes would directly affect their well-being. Income from private pensions, assets, and earnings are relatively more important for higher-income elderly individuals, who have more diverse income sources. The trend from private sector defined benefit to defined contribution pension plans has shifted a greater share of the responsibility for retirement security to individuals, and made that security more dependent on choices they make. A significant subset of the population is unlikely to be able to sustain their standard of living in retirement without higher pre-retirement saving.
\end{abstract}

James M. Poterba

Department of Economics, E17-214

MIT

77 Massachusetts Avenue

Cambridge, MA 02139

and NBER

poterba@nber.org

An online appendix is available at:

http://www.nber.org/data-appendix/w19930 
Richard T. Ely, the first Secretary of the American Economic Association and its sixth President, was born in 1854 near Buffalo, New York. He had an unusually long and productive career. He retired from Northwestern University at the age of 79, after being recruited at the age of 72 from the University of Wisconsin, where he had spent 33 years on the faculty. When Ely died at the age of 89, he had outlived all but about one percent of the men in his birth cohort, according to the life tables for white men born in the United States in the 1850s compiled by J. David Hacker (2010). Times have changed. For the 2010 U.S. birth cohort, Felictie Bell and Michael Miller (2005) forecast that 35 percent of men will reach their 89th birthday and that two percent will celebrate their 102nd birthday.

Longer life expectancy, brought about by dramatic reductions in infant mortality in the early twentieth century and by ongoing improvements in mid-life and old-age mortality in more recent decades, has profound economic consequences for individuals as they engage in lifecycle planning, and for economies as the average age of their population rises. This paper focuses on the challenges that an aging population will pose for retirement saving in the United States. It is divided into eight sections. The first provides a brief overview of falling mortality rates at older ages. It highlights their implications for lifecycle planning as well as the substantial heterogeneity in mortality improvements in different parts of the income distribution. The next section explores the macroeconomic consequences of population aging, drawing heavily on the findings of a recent study by the National Research Council (2012). Section three shifts attention to financial support for retirement, describing the wide variation in the sources of income for the U.S. population over the age of 65. Just as with mortality improvements, heterogeneity is key. There are large differences between the upper and lower strata of the income distribution in their retirement finances. The fourth section shifts from income to wealth, and describes the balance sheets of elderly households. Section five documents the changes over the last three decades in the employer-provided pension system in the private sector and how that has affected retirement preparation. Section six explores the relationship between an individual's saving rate while working, career length, rates of return, and the income replacement rate in retirement. It reports calculations that underscore the challenge of providing for lengthy retirement periods in an economic environment that offers low long-term rates of return. The seventh section describes 
strategies for promoting saving, highlighting recent findings on automatic enrollment and other approaches derived from behavioral economics. There is a brief conclusion.

I. Longer Lifespan: The Changing Setting for Retirement Planning

Rising life expectancies, in the United States and around the world, are one of the most extraordinary achievements of the 20th century. Table 1 shows that a U.S. man born in 1900 had a life expectancy of 51.5 years, and less than a fifty percent chance of reaching age 65. A century later, a newborn male was projected to have a life expectancy of 80 years, and an 86 percent chance of celebrating his 65th birthday. For a woman, the gains were nearly as large. In 1900, a newborn girl's life expectancy was 58.3 years and she had a 57 percent chance of reaching her 65th birthday. In 2000, life expectancy at birth was 84.2 years and the probability of reaching the age of 65 was projected to exceed 90 percent. Between 1900 and 2000, the expected share of a newborn boy's life that would be accounted for by years lived beyond the age of 65 rose from 12.2 percent to 22.0 percent. For newborn girls, the change was from 17.9 to 24.7 percent. The changes at even older ages have been more dramatic. In the 2000 birth cohort, males and females could expect to live 4.3 and 6.1 percent of their lives, respectively, beyond age 85 . The corresponding values for the 1900 birth cohort were 1.1 and 2.9 percent. Karen Eggleston and Victor Fuchs (2012) observe that prospectively, most of the extension of life length is likely to be due to reductions in mortality rates at older ages, which implies continued growth in the population share accounted for by the "oldest old."

Table 1: Life Expectancy at Birth and Age 65, 1900-2000 Birth Cohorts

\begin{tabular}{|l|l|l|l|l|l|l|}
\hline $\begin{array}{l}\text { Birth } \\
\text { Cohort }\end{array}$ & \multicolumn{2}{|l|}{ Men } & \multicolumn{3}{l|}{ Women } \\
\hline & $\begin{array}{l}\text { Life } \\
\text { Expectancy } \\
\text { at Birth }\end{array}$ & $\begin{array}{l}\text { Probability of } \\
\text { Reaching Age } \\
65\end{array}$ & $\begin{array}{l}\text { Life } \\
\text { Expectancy } \\
\text { at 65 }\end{array}$ & $\begin{array}{l}\text { Life } \\
\text { Expectancy } \\
\text { at Birth }\end{array}$ & $\begin{array}{l}\text { Probability of } \\
\text { Reaching } \\
\text { Age 65 }\end{array}$ & $\begin{array}{l}\text { Life } \\
\text { Expectancy } \\
\text { at 65 }\end{array}$ \\
\hline 1900 & 51.5 & 46.7 & 13.5 & 58.3 & 57.8 & 18.0 \\
\hline 1950 & 72.5 & 75.9 & 17.6 & 78.5 & 84.7 & 20.3 \\
\hline 2000 & 80.0 & 86.1 & 20.4 & 84.2 & 90.6 & 23.0 \\
\hline
\end{tabular}

Source: Bell and Miller (2005), Table 7.

For an individual, holding constant the age-wage profile and transfers received from previous generations and from the government, an increase in life expectancy will affect the 
optimal level and path of consumption, and potentially the age profile of labor supply. Unless lifecycle labor supply rises or the individual receives larger transfers as a consequence of a longer life, a longer lifespan will translate into a lower level of annual consumption. This will entail both a higher saving rate when working, and a lower rate of annual consumption when not.

John Shoven and Sita Slavov (2013) point out individuals should not plan based only on average life expectancy, but that they must also consider the upper tail of the distribution of life length - a key insight of stochastic lifecycle models. Table 2 presents the age to which 20 percent of the men and women who reach age 65 can expect to live. For a man reaching the

Table 2: Life Expectancy and the Probability of Living to Very Old Age

\begin{tabular}{|l|l|l|l|l|}
\hline Birth Cohort & \multicolumn{2}{|l|}{ Men } & \multicolumn{2}{l|}{ Women } \\
\hline & $\begin{array}{l}\text { Expected Age at } \\
\text { Death } \\
\text { Conditional on } \\
\text { Reaching Age 65 }\end{array}$ & $\begin{array}{l}\text { Age at Which } \\
\text { Only 20\% of } \\
\text { Those Who } \\
\text { Reach Age 65 } \\
\text { Will Still Be } \\
\text { Alive }\end{array}$ & $\begin{array}{l}\text { Expected Age at } \\
\text { Death } \\
\text { Conditional on } \\
\text { Reaching Age 65 }\end{array}$ & $\begin{array}{l}\text { Age at Which } \\
\text { Only 20\% of } \\
\text { Those Who } \\
\text { Reach Age 65 } \\
\text { Will Still Be } \\
\text { Alive }\end{array}$ \\
\hline 1900 & 78.5 & 86.2 & 83.0 & 91.5 \\
\hline 1950 & 82.6 & 90.5 & 85.3 & 93.4 \\
\hline 2000 & 85.4 & 93.6 & 88.0 & 96.3 \\
\hline
\end{tabular}

Source: Bell and Miller (2005),Table 7, for columns 2 and 4; author's calculations, columns 3 and 5.

age of 65 in 2015, remaining life expectancy is 18.6 years, but he has a 20 percent chance of living at least twenty-five years and dying beyond his 90th birthday. For women in this birth cohort, life expectancy at 65 is 20.3 years, but one in five will live to the age of 93 . The expected age of death for the second-to-die in a married couple, both aged 65, is even greater. For both men and women, the increase in the age that 20 percent of those who reach age 65 can expect to reach has roughly kept pace with the increase in remaining life expectancy at age 65.

These statistics not only suggest that the relevant planning horizon for many individuals may be substantially longer than average life expectancy, but they also highlight the growing importance of saving and financial planning challenges at the oldest ages. Dementia and reduced cognitive function can complicate financial planning for the oldest old. Sumit Agarwal, John Driscoll, Xavier Gabaix, and David Laibson (2009) report that cognitive function and financial literacy decline once individuals pass their mid-50s. Because the number of "oldest old," 
traditionally defined as those older than 85, has historically been relatively small, these issues have not received much attention, but they are likely to become increasingly important.

Aggregate data on mortality improvement also conceal substantial differences in the rate of longevity improvement for individuals with different characteristics. The drop in old-age mortality rates has been particularly pronounced for those in the upper strata of the socioeconomic status distribution. Table 3 presents estimates of life expectancy at ages 65 and 85 for U.S. men in the upper and lower half of the earnings distribution for birth cohorts between 1912 and 1941. Individuals are classified based on their Social Security earnings between ages 45 and 55. The sample excludes those without any earnings, so the lower half of the earnings distribution may exclude many of the individuals in the poorest health.

Table 3: Life Expectancy for Men, Stratified by Lifetime Earnings, 1912-1941 Birth Cohorts

\begin{tabular}{|l|l|l|l|l|}
\hline \multirow{2}{*}{ Birth Cohort } & \multicolumn{2}{|l|}{ Life Expectancy at 65 } & \multicolumn{2}{l|}{ Life Expectancy at 85 } \\
\cline { 2 - 5 } & $\begin{array}{l}\text { Bottom Half of } \\
\text { Earners }\end{array}$ & $\begin{array}{l}\text { Top Half of } \\
\text { Earners }\end{array}$ & $\begin{array}{l}\text { Bottom Half of } \\
\text { Earners }\end{array}$ & $\begin{array}{l}\text { Top Half of } \\
\text { Earners }\end{array}$ \\
\hline 1912 & 14.8 & 15.5 & 6.2 & 5.9 \\
\hline 1922 & 15.3 & 17.5 & 6.2 & 6.9 \\
\hline 1932 & 15.7 & 19.6 & 6.2 & 8.0 \\
\hline 1941 & 16.1 & 21.5 & 6.1 & 9.0 \\
\hline
\end{tabular}

Source: Hilary Waldron (2007), Table 4.

Table 3 illustrates the apparent widening of the "mortality gradient." This gradient and the associated disparity in health status have been documented Ellen Meara, Seth Richards, and David Cutler (2008) and Joseph Pijoan-Mas and Jose-Victor Rios-Rull (2013), among others. The gradient has a number of important implications for the analysis of retirement security and for public policies. For individuals in the upper strata of the socio-economic distribution, the relevant planning horizon for retirement saving may be substantially longer than population-wide measures of life expectancy suggest. In addition, as Dana Goldman and Peter Orszag (2014) observe, estimates of the present discounted value of lifetime Social Security and Medicare benefits net of payroll taxes for individuals at different places in the income distribution are sensitive to assumptions about the mortality gradient. The sources of the mortality gradient are not well understood, and it may be affected by various societal changes. For example, Poterba, Steven Venti, and David Wise (2014) demonstrate that educational attainment is strongly 
correlated with health status at retirement and with an individual's position in the lifetime earnings distribution. This raises the possibility that a changing distribution of educational attainment and other factors across cohorts may affect the evolution of the mortality gradient.

In addition to their implications for individual retirement planning, longer life spans also have important consequences for government transfer programs. Because Social Security, Medicare, and Medicaid provide much greater benefits to older than to younger individuals, and in the case of Medicare only provide benefits for those over the age of 65, an aging population will imply significant increases in public sector outlays on these programs. This increase in fiscal burdens is one of the key macroeconomic effects of an aging population. Modifications in eligibility rules and program benefits, the "entitlement reform" debate, may attenuate, but are unlikely to undo, these fiscal demands. The heterogeneity of the elderly population needs to be recognized in discussions of program reforms. Raising the age of eligibility for Medicare and the normal retirement age for Social Security, for example, would likely affect the labor supply of older individuals and it would affect individuals differently depending on their health status and capacity to continue working at advanced ages.

Changes in government transfer programs are one way that a society may respond to an aging population. Raising transfers from younger to older individuals can support the consumption of the elderly. The burden of such a policy on the younger generation, relative to the benefit for a member of the older generation, depends on the relative sizes of the young and old cohorts, which in turn is determined by the rate of population growth and, potentially, by the immigration rate. In economies with rapid population growth, the younger cohort is much larger than the older one and the required tax on the young to support the old is smaller than in an economy that has grown more slowly, and in which the relative sizes of the younger and older cohorts is closer to equality. This is one of the reasons why transfer programs targeted to the elderly were less burdensome on younger individuals when they were created in the last century, at a time of rapid population growth, than they will be prospectively.

A key issue that underpins analysis of proposals to raise program eligibility ages is whether longer life spans are associated with longer periods of disability, as might be the case if modern medical advances succeeded in prolonging life for those in poor health, or longer periods of good health, as might be the case if changes in lifestyle or medical progress delayed the onset 
of debilitating diseases. Recent studies support the second view: age-specific disability rates have fallen as life expectancy has risen. Cutler, Kaushik Ghosh, and Mary Beth Landrum (2014) estimate that disability-free life expectancy for a 65-year old man was 9.2 years in 1992, while disabled life expectancy was 6.2 years. Between 1992 and 2005, they estimate that disabilityfree life expectancy rose by 1.7 years, while disabled life expectancy fell by 0.4 years.

Disability-free life expectancy rose by more than the increase in life expectancy, suggesting that the age of onset of major disabilities receded even more quickly than the advance in life expectancy would suggest. For women, the pattern was even more pronounced. Disability-free life expectancy in 1992 was 8.4 years. It increased by 1.6 years by 2005, while disabled life expectancy, which was 9.4 years in 1992, fell by 1.4 years. Heterogeneity is evident in the decline in disability rates, just as in mortality changes. For those in lower socio-economic strata, the improvement in disability-free life expectancy is substantially smaller than that for the population at large. Nevertheless, it appears that for a substantial part of the population reaching the age of traditional retirement, health limitations do not preclude at least some additional years of work. The prospective labor supply decisions of individuals in their 60s and even 70s can have an important impact on both the fiscal and macroeconomic effects of an aging population.

\section{Macroeconomic Implications of an Older Population}

Falling age-specific mortality rates have important implications for individual lifecycle planning, but they also affect the aggregate population age distribution and can therefore have macroeconomic consequences. Birth rates, immigration rates, and death rates all combine to determine the population age structure. In the U.S., recent improvements in longevity have coincided with falling birth rates. Mark Mather (2012) reports that the average number of children born to a U.S. woman over her lifetime declined from 3.5 during the late 1950s and early 1960s to less than 2.0 by the mid-1970s, a value that has varied relatively little since then.

Table 4 reports the historical and projected share of the U.S. population over the age of 65, over the age of 85, and under the age of 18 between 1900 and 2050. Between 1950 and 2000, the percentage of the U.S. population over the age of 65 rose from roughly 8 to 12 percent. It is projected to rise by an even larger proportion, to 20.9 percent, by 2050. Between 1950 and 
2050, the share of the population over the age of 85 is expected to rise ten-fold. The population share over 85 in 2050 will roughly equal the share over 65 in 1900.

Table 4: Historical and Projected Age Structure of the U.S. Population, 1900-2050

\begin{tabular}{|l|l|l|l|}
\hline Year & $<18$ & $>65$ & $>85$ \\
\hline 1900 & 40.8 & $4.1 \%$ & $0.2 \%$ \\
\hline 1950 & 31.0 & 8.1 & 0.4 \\
\hline 2000 & 25.7 & 12.4 & 1.5 \\
\hline 2025 & 22.6 & 18.8 & 2.1 \\
\hline 2050 & 21.5 & 20.9 & 4.2 \\
\hline
\end{tabular}

Source: Rows 1-3, Frank Hobbs and Nicole Stoops (2002), Figure 2-7 and Jennifer Cheeseman Day (1996), Table E; Rows 4 and 5, U.S. Census Bureau, Population Division (2012), Table 3.

The data in Table 4 can be used to compute an "elderly dependency ratio," which equals the number of elderly individuals divided by the number of prime-age individuals. If we define this ratio as the number of those over the age of 65 relative to those 19-64, the entries in Table 4 imply a rising elderly dependency ratio, from 0.20 in 2000, to 0.32 in 2025, to 0.36 in 2050 . The "total dependency ratio," which can be defined as (population under 18 + population over 65)/(population 19-64), rises less over the same period. It increases from 0.62 in 2000 , to 0.70 in 2025, to 0.74 in 2050 .

The relative roles of family and government in caring for young and elderly dependents is different, so it remains an open question whether combining children and the elderly to construct a total dependency burden is appropriate. The dependency ratios reported here are illustrative, and similar concepts can be found in many other studies. Diane Lim Rogers, Eric Toder, and Langdon Jones (2000) are one of many studies that explore the long-run effects of changing dependency burdens.

The potential macroeconomic consequences of the aging of the U.S. population have been widely discussed. The National Research Council (2012) examines a number of the economic effects that may be associated with population aging, and also assesses the uncertainties associated with them. The foregoing discussion noted that an increase in the size of the public sector is one of the most predictable effects. To illustrate this, Table 5 reports measures of age-specific consumption, labor income, and net government transfers from the National Transfer Accounts project, a multi-country study of the patterns of resource use and 
public and private transfers across generations. The data in Table 5 correspond to the U.S. economy in 2003. The rise in the relative price of medical care since then, and the greater share of such care in the budget of the elderly, suggests that the consumption of the elderly has probably risen, relative to that of other age groups, since this benchmark year.

The data in Table 5 indicate that average per capita consumption rises with age in crosssectional data. It "dips" between the ages of 15-19 and 20-29, reflecting the decline of educational outlays, but rises again after age 30. The consumption level of those 85-89 in 2003 was roughly fifty percent greater than that of those in their early 30s. The differences in per capital consumption by age suggest that changing age composition could affect the economy's saving rate.

Table 5: Average Consumption, Labor Income, and Net Government Transfers by Age, 2003 (\$2003)

\begin{tabular}{|l|l|l|l|}
\hline Age Group & Consumption & Labor Income & Net Government Transfer \\
\hline $0-4$ & $\$ 13821$ & $\$ 0$ & $\$ 4998$ \\
\hline $5-9$ & 22785 & 0 & 11971 \\
\hline $10-14$ & 26810 & 0 & 12201 \\
\hline $15-19$ & 29140 & 2142 & 9713 \\
\hline $20-24$ & 27200 & 14984 & 2842 \\
\hline $25-29$ & 27001 & 30754 & -3294 \\
\hline $30-34$ & 30205 & 40388 & -7063 \\
\hline $35-39$ & 31063 & 46302 & -9887 \\
\hline $40-44$ & 31750 & 49875 & -10827 \\
\hline $45-49$ & 33895 & 51898 & -12012 \\
\hline $50-54$ & 36559 & 51136 & -12340 \\
\hline $55-59$ & 39694 & 45256 & -10628 \\
\hline $60-64$ & 41455 & 30251 & -3331 \\
\hline $65-69$ & 41447 & 14837 & 8203 \\
\hline $70-74$ & 42558 & 7466 & 11409 \\
\hline $75-79$ & 42276 & 3807 & 13775 \\
\hline $80-84$ & 42496 & 2046 & 16588 \\
\hline $85-89$ & 46407 & 1215 & 23391 \\
\hline
\end{tabular}

Source: Data provided by Gretchen Donehower based on Ronald Lee, Donehower, and Tim Miller (2011).

The labor income data in Table 5 display the expected pattern, peaking between the ages of 45 and 54 and declining sharply between the late 50s and early 70s. The table also shows that net public transfers play a critical role in supporting the consumption of older individuals. The 
average net government transfer to those between the ages of 70 and 74 was $\$ 11,409$, roughly comparable to the average annual transfer to school-age children between the ages of 5 and 15 . Beyond age 75, however, net transfers continue to rise. For someone between the ages of 85 and 89 , the average annual net transfer, $\$ 23,391$, is more than double that for a $70-74$ year old. The young benefit primarily from spending on public education and child-targeted antipoverty programs such as Medicaid and SNAP. For the elderly, the key transfer programs are Social Security, Medicare, and Medicaid.

The age-specific transfer patterns in Table 5 are broadly consistent with recent estimates by the Congressional Budget Office (2013) that are benchmarked to 2006. The CBO estimates that net transfers, defined as federal government transfers minus taxes, to households headed by someone over the age of 65 averaged $\$ 13,900$, while the corresponding transfers for non-elderly households with and without children were $-\$ 16,900$ and $-\$ 15,800$ respectively. The CBO (2013) also reports that in 2006, the 15 percent of households aged 65+ received over 60 percent of federal transfers.

Under the strong assumption that relative age-specific income and spending patterns remain constant over time, the data in Table 5 can be combined with information on the historical and projected population in different age groups to calculate how changes in population structure could affect per capital consumption and labor earnings. Louise Sheiner (2014) presents a more detailed summary of the potential effects of prospective changes in population age structure on per capita consumption.

Projected per capita consumption in year $\mathrm{t}, \mathrm{C}_{\mathrm{t}}^{*}$, equals:

$$
\mathrm{C}_{\mathrm{t}}^{*}=\Sigma_{\mathrm{i}} \text { Popi, }^{*}{ }^{*} \mathrm{C}_{\mathrm{i}, 2003}
$$

$\mathrm{Pop}_{\mathrm{i}, \mathrm{t}}$ is the projected (or historical) share of the population in age group $\mathrm{i}$ in year $\mathrm{t}$, and $\mathrm{C}_{\mathrm{i}, 2003}$ is per capita consumption for age group i as reported in Table 5. A similar calculation yields projected per capita labor income, $L^{*}$, based on the current pattern of earnings by age. (2) $\quad \mathrm{L}_{\mathrm{t}}{ }_{\mathrm{t}}=\Sigma_{\mathrm{i}} \mathrm{Pop}_{\mathrm{i}, \mathrm{t}}{ }^{*} \mathrm{~L}_{\mathrm{i}, 2003}$

The ratio of $\mathrm{L}_{\mathrm{t}} / \mathrm{C}_{\mathrm{t}}$ for different years provides information on how per capita labor earnings will evolve relative to "notional" per capita consumption as a result of the changing population age distribution. Using the 2010 age distribution as a benchmark, labor earnings relative to consumption declines by 10 percent by 2050: $\left[\mathrm{L}^{*}{ }_{2050} / \mathrm{C}^{*}{ }_{2050}\right] /\left[\mathrm{L}^{*}{ }_{2010} / \mathrm{C}^{*}{ }_{2010}\right]=0.90$. Most of 
this decline occurs by 2030. By comparison, this ratio for 1990 equaled 1.05, reflecting the larger relative population in prime earning years then than in 2010. In 1970, the burdens of educating the Baby Boomers brought this ratio well below one: $\left[\mathrm{L}^{*}{ }_{1970} / \mathrm{C}^{*}{ }_{1970}\right] /\left[\mathrm{L}^{*}{ }_{2010} / \mathrm{C}^{*}{ }_{2010}\right]=0.88$.

The prospective decline in this ratio, like the rise in the elderly dependency ratio, signals the pressure that changing age structure will place on the level of per capita consumption in the U.S. economy. All else equal, between 2010 and 2030, to sustain the level of per capita consumption at all ages in 2010, total consumption would need to rise by 2.2 percent $\left(C^{*}{ }_{2030} / C^{*}{ }_{2010}=1.022\right)$. At the same time, per capita labor earnings are projected to fall by 7.8 percent $\left(\mathrm{L}^{*}{ }_{2030} / \mathrm{L}^{*}{ }_{2010}=0.928\right)$. If the age-specific level of earnings does not change, absent other sources of support for consumption, such as rising capital income, per capita consumption in 2030 would need to fall relative to 2010.

There are many potential transition paths that an economy can follow when faced with a demographic transition that requires a reduction in steady-state consumption. The economy's capital accumulation path determines which trajectory it follows. Ellen McGrattan and Edward Prescott (2013) recognize this point, and argue that pursuing tax policies that would encourage capital deepening could raise the productivity of future workers relative to that of today's workers, thereby shifting the path of future $L^{*}$ values and potentially avoiding the need to reduce per capita consumption. Encouraging human capital investments could also raise age-specific average earnings. Late-life age-specific average earnings could also rise if the labor force participation rate for older workers increased.

Cutler, Poterba, Sheiner, and Lawrence Summers (1990) compute the consumption trajectory that a social planner would choose if she were solving a textbook Ramsey optimal growth problem, subject to the changing support ratios associated with population aging. They point out that the optimal consumption path in an economy that is growing older because of declining fertility may differ from that in one that grows older because of declining mortality. When the population is aging because of declining old-age mortality, and retirement dates are not increasing, then the rising dependent population results in lower per-capita consumption. If the population is aging because the birth rate has fallen and the labor force is growing more slowly, however, then the economy benefits in the near term from a reduction in the level of investment that is needed to preserve the capital-labor ratio. This frees up resources that can 
support consumption. Is this a relevant consideration today? The annual rate of growth of the U.S. population aged 20-64 averaged 1.27 percent between 1960 and 2010; it is projected to average only 0.43 percent between 2010 and 2050. The positive consumption effect of this decline in labor force growth, however, is modest relative to negative effect of the falling labor force to population ratio and it attenuates but does not reverse this effect. Twenty-five years ago, when Cutler, Poterba, Sheiner, and Summers (1990) investigated this issue, the prospective decline in labor force growth effect was larger, and the negative pressure from rising dependency ratios was smaller, than today. In some cases then, the Ramsey social planner's response to incipient population aging involved raising, then reducing, per capita consumption. That is no longer the case for plausible parameter choices.

The net transfer patterns by age group that are shown in Table 5 suggest that the changing population age structure between 2010 and 2050 will place substantial demands on the public sector. This fiscal consequences are discussed in National Research Council (2010). The data on net government transfers in Table 5, combined with population projections for various years, suggest that population aging could raise the age-weighted net per capita transfer, which is \$-279 in 2010, to $\$ 893$ by 2030 and $\$ 1023$ by 2050 . Note that the information in Table 5 predates the expansion of various transfer programs in connection with the Great Recession; these program changes may have affected the age-specific patterns of taxes and spending to some degree.

The fiscal effects of population aging have attracted substantial attention, but there are at least two other potential macroeconomic consequences that could have first-order effects on future living standards: changes in equilibrium rates of return in capital markets, and effects on the rate of technological progress. Although different, both effects can compound over time. For example, the potential decline of ten percent between 2010 and 2030 in the ratio of per capita labor earnings to per capita consumption "needs" would be completely erased if the rate of productivity growth increased by 0.5 percentage points per year, and that productivity advance translated into growth in labor earnings.

When analyzing the potential effects of population aging on rates of return, it is important to recognize that in integrated global capital markets, the age structure of the global population can be at least as important an influence on equilibrium rates of return as the domestic age structure, and perhaps much more important. For assets that are traded in fully integrated global 
capital markets, the domestic age structure should not matter; the global age structure, and the associated global capital-labor ratio, should be the key determinant of rates of return. Although the U.S. population grows older in the next four decades, the rate at which the U.S. ages is slower than that of many other nations, including most of Western Europe and China. Falling birth rates in both locations lead to sharp changes in prospective population age structure. In calibrated multi-country models of global capital accumulation that recognize the shifting global age structure, such as Axel Börsch-Supan, Alexander Ludwig, and Joachim Winter (2006), the equilibrium rate of return declines as a result of the rising global ratio of capital to labor, but the effect is less than one percentage point per year. In some modeling scenarios with fully integrated global capital markets, the effect is substantially smaller. One scenario that yields much smaller effects on returns allows for rising per capita labor supply as the population ages. This is just one of the economic adjustments that are likely to limit the magnitude of any decline in equilibrium returns.

A number of empirical studies have explored the relationship between a nation's population age structure and its capital market returns, with mixed results. Robert Arnott and Denis Chaves (2012), who study a broad cross-section of countries, and Zheng Liu and Mark Spiegel (2011), who study the U.S. historical record, among others, find a positive correlation between population age structure, particularly the fraction of the population of prime working age, and returns. Arnott and Chaves focus on equity market returns, and they suggest that investors should prepare for a long prospective period during which returns will fall below their historical averages. Other studies, however, find weaker links between demography and returns, and point out that the effective "degrees of freedom" in studies linking demography to rates of return can be quite small. Poterba (2001), for example, does not find any robust relationship between age structure and equity returns in the U.S., U.K., or Canada. The large fluctuations in equity values markets over the last six years are a reminder of the difficulty of detecting the modest differences in expected returns that might be associated with demographic forces.

One specific concern, raised more frequently in the financial press than in the research literature, is that there may be an asset market "meltdown" when the large cohort of U.S. baby boomers reach retirement and begin to draw down their retirement savings, depressing asset prices. This scenario seems unlikely for two reasons. First, demographic changes are largely 
predictable, and predictable events generally do not have large effects on asset values. It would be difficult for the capital markets to be surprised by the retirement of the baby boomers. Second, for those who have accumulated assets while working, the rate at which these assets are drawn down tends to be quite slow. The U.S. Government Accountability Office (2006) concludes that the draw-down of financial assets in retirement is likely to be gradual at best.

After reviewing the theoretical work, the calibrated modeling, and the empirical research on the links between demography and rates of return, the National Research Council (2012) report concludes that these effects are likely to be modest, particularly when viewed against the backdrop of equity market volatility. However, even modest effects on annual returns could cumulate to a substantial effect on wealth accumulation over a period of several decades. This point is emphasized later, in the discussion of returns and the opportunity to build retirement wealth.

The second long-run macroeconomic effect, the possibility that a shifting population age structure may affect the rate of technological change, is also one that could cumulate over several decades. As with rate of return effects, the global as well as domestic population age structure may matter for the production of new ideas and the advance of technology. The empirical evidence on this issue is limited, and does not reach a clear consensus. Some suggest that older workers are less productive, or that they are less flexible in adapting to new technologies than their younger counterparts. While many empirical studies have adopted a quadratic approach to modeling earnings as a function of age or labor market experience, and found an inverted-U shaped age-earnings pattern, the empirical evidence on declining earnings at older ages is limited. Although Richard Johnson and David Neumark (1996) report falling wages as workers approach retirement age, a number of other studies, including Kevin Murphy and Finis Welch (1990) and María Casanova (2013), find that age-earnings profiles plateau, but do not decline.

This finding is supported by a growing literature on age-productivity relationships that relies on firm-level microdata. Börsch-Supan and Matthias Weiss (2013), for example, find no increase in the rate of errors in a Mercedes-Benz factory as workers age. While the standard errors on the estimated error rates are higher for workers over the age of 65 and under the age of 25, there is statistically significant evidence of higher error rates for workers under the age of 30 , but no evidence of higher error rates as workers age into their 60s. David Bloom and Alfonso 
Sousa-Poza (2013) and Börsch-Supan (2013) present summaries of the age-productivity literature; neither finds compelling evidence that older workers are less productive. While there may be some occupations, for example those that demand heavy physical labor, in which older workers are not as productive as their younger counterparts, these studies suggest that this pattern is difficult to detect more broadly.

Another concern, and one that appears to have more empirical support, is that an aging population will reduce the level of entrepreneurial or innovative activity. James Liang, Hui Wang, and Edward Lazear (2013) study the relationship between a nation's entrepreneurship rates as measured by the Global Entrepreneurship Monitor and the fraction of its population aged 20 to 64 that is between the ages of 20 and 39. A one percentage point increase in the share of the working age population in their 20s and 30s is associated with a five percent increase in the entrepreneurship rate. The mean entrepreneurship rate in their 59-country sample is 9.5 percent, so at the mean, a five percentage point drop in the share of 20-39 year olds would reduce the entrepreneurship rate by more than two percentage points. In a related vein, Benjamin Jones, E. J. Reedy, and Bruce Weinberg (2014) study the relationship between age and major scientific contributions. They find that while the age at which individuals make major breakthroughs varies across fields and has varied over time, there is systematic evidence of a declining rate of such innovations after middle age. Whether the association between entrepreneurship, innovation, and population age structure is causal is an unresolved question, and how much a change in entrepreneurship affects the rate of technological change is also an open issue.

The National Research Council (2012) examined the relationship between population age structure, measured in ten-year age increments, and the rate of aggregate productivity growth across OECD countries. Productivity growth does appear to be related to age structure, with the fraction of workers close to age 40 having the most positive impact on productivity, and a smooth decline for both younger and older workers. The statistical relationship between the average age of the workforce and the rate of productivity growth is not robust, however; it is sensitive to minor changes in specification. For most specifications that were examined, the demography-related change in the productivity growth rate over the next two decades is less than one tenth of one percent in absolute value, suggesting that this effect on future consumption levels is small relative to the direct effects of rising dependency burdens. 


\section{The Heterogeneous Nature of Retirement Income Support}

Retirement income support in the United States is often described as a "three-legged stool” consisting of government-provided Social Security, employer-based private pension plans, and private saving. Social Security is a component of retirement income for nearly all elderly households. It is also the subject of ongoing policy debate, with some calling for scaling back benefits, particularly for well-to-do elderly households, and others suggesting program expansion to strengthen retirement security for low-income elderly households. The second, income from employment-based pensions, is relevant for about half of the elderly. This component of the retirement saving system has also undergone substantial transformation in the last three decades, with a shift from defined benefit (DB) to defined contribution (DC) pension plans in the private sector. This shift has replaced one set of risks, for example the risk of job loss before the latecareer years when DB plans generate their largest retirement benefit accruals, with another set, including participant decision risk, financial market risk, and annuitization risk. The third component, private saving outside the retirement saving system, represents an important source of support for only a fraction,perhaps one quarter, of retired households, skewed toward the upper strata of the income distribution.

Retirement support arrangements of the elderly are heterogeneous. Only about one quarter of the elderly population draws substantial support from all three legs of the "three legged stool." A large and growing fraction of those over the age of 65, particularly those in the higher strata of the income distribution, rely on earnings for a share of their support. For many elderly individuals in the bottom half of the income distribution, Social Security benefits represent their primary source of support.

Table 6 reports data from the Current Population Survey on the sources of income for individuals over the age of 65 in 2013. Following Patrick Purcell (2009) and others, individuals are disaggregated into quartiles based on total income. The analysis focuses on individuals, rather than households, which requires allocating joint income in couples to one spouse or the other. It also may understate the effective living standard of the roughly 11 percent of those over the age of 65 who are part of a household in which the household head is younger than 65. Some of these households are married couples, while others are multi-generational households. 
Focusing on individuals helps shed light on the circumstances of elderly women, perhaps at some cost in the extent to which the data describe the circumstances of elderly men. Elderly women are less likely than elderly men to be part of a married couple. The U.S. Census Bureau (2013) reports that 74.9 percent of men between the ages of 65 and 74 were in households that were "married, with spouse present." Even for men over the age of 85, 51.3 percent were in married households. For women, 55.3 percent of the 65-74 year old cohort is married; only 16.1 percent of those $85+$ are in couples.

Focusing on individuals may understate the effective living standard of a low-income individual who is part of a married couple and whose spouse has substantial income, and it reduces the fraction of the respondents with any type particular type of income relative to the analogous share of households. For example, in household data, if one spouse in a married couple receives income from an employer provided pension, the household will be classified as receiving such income. When the individual is the focus of the tabulation, however, only one of the two individuals in the household will be classified as receiving such income.

Table 6: Income Sources for Individuals Aged 65+, 2013, by Total Income Quartile

\begin{tabular}{|l|l|l|l|l|l|l|l|l|}
\hline & \multicolumn{3}{|l|}{ Percentage Receiving Income Type } & \multicolumn{3}{l|}{ Percentage of Total Income } \\
\hline Quartile: & Lowest & Second & Third & Highest & Lowest & Second & Third & Highest \\
\hline Social Security & $73.3 \%$ & $94.6 \%$ & $90.1 \%$ & $78.1 \%$ & $85.0 \%$ & $83.5 \%$ & $56.5 \%$ & $18.1 \%$ \\
\hline Earnings & 4.3 & 8.2 & 22.6 & 51.3 & 2.3 & 4.2 & 12.9 & 43.7 \\
\hline Pension Income & 5.4 & 19.8 & 52.3 & 56.2 & 2.5 & 6.2 & 21.1 & 21.8 \\
\hline Asset Income & 26.4 & 40.1 & 57.0 & 74.8 & 2.7 & 3.7 & 6.8 & 13.8 \\
\hline $\begin{array}{l}\text { SSI/Public } \\
\text { Assistance }\end{array}$ & 8.0 & 2.2 & 0.7 & 0.4 & 6.6 & 1.0 & 0.2 & 0.0 \\
\hline Other Income & 2.5 & 5.0 & 8.4 & 12.6 & 1.0 & 1.5 & 2.6 & 2.6 \\
\hline $\begin{array}{l}\text { Mean Individual } \\
\text { Income }\end{array}$ & $\$ 6756$ & $\$ 15401$ & $\$ 26640$ & $\$ 78180$ & $\$ 6756$ & $\$ 15401$ & $\$ 26640$ & $\$ 78180$ \\
\hline
\end{tabular}

Source: Author's calculations using March 2013 Current Population Survey data described by Miriam King, et al. (2013).

The entries in Table 6 show that for individuals over the age of 65 and in the bottom half of the income distribution for this age group, about 84 percent of retirement support is from Social Security benefits. In the bottom quartile, only 73 percent of individuals report receiving Social Security. While this may reflect a lack of eligibility on the part of some, particularly older individuals, it may also reflect measurement error. Howard Iams and Purcell (2013) 
explore under-reporting of Social Security income by matching household survey data with administrative record data. They find that 7 percent of CPS respondents with Social Security benefit payments in the Payment History Update System fail to report any such income in the survey. Under-reporting may be more prevalent among those with lower incomes.

The importance of Social Security as a source of retirement income for those in the bottom half of the income distribution reflects both the low saving rate for many workers and the progressivity of the Social Security benefit formula. The ratio of annual Social Security benefits to career average earnings, a measure of the "replacement rate," is higher for those with lower earnings. Table 7 reports estimates of this replacement rate for individuals at various points in

Table 7: Social Security Earnings Replacement Rates, 2013

\begin{tabular}{|l|l|l|}
\hline $\begin{array}{l}\text { Career Average Earnings as a } \\
\text { Percentage of National Average } \\
\text { Wage }\end{array}$ & $\begin{array}{l}\text { Career Average } \\
\text { Earnings Level }\end{array}$ & $\begin{array}{l}\text { Replacement Rate, } \\
\text { Retirement at Age 65 }\end{array}$ \\
\hline 25 Percent & $\$ 11,207$ & $77.4 \%$ \\
\hline 45 Percent & $\$ 20,172$ & 56.3 \\
\hline 100 Percent & $\$ 44,826$ & 41.7 \\
\hline 160 Percent & $\$ 71,722$ & 34.6 \\
\hline Social Security Earnings Limit & $\$ 113,700$ & 27.9 \\
\hline
\end{tabular}

Source: Board of Trustees, Federal OASDI and Federal DI Trust Funds (2013), Table V.C.7.

the wage distribution. For an individual at the 25th percentile of the wage distribution, the replacement rate is more than 75 percent. Olivia S. Mitchell and John Phillips (2006) perform calculations related to those in Table 7, and suggest that replacement rates computed using actual rather than stylized wage profiles are likely to exceed those in Table 7. The high replacement rates from Social Security alone are essential to remember when considering issues such as the incomplete coverage of private pensions, since they attenuate the need for additional income for a subset of elderly individuals.

The entries in Table 6 also show that pension income is far from a universal source of retirement income support. Only about 12 percent of those in the lower half of the income distribution report receiving private pension income. The CPS coverage of income paid out from defined contribution pension plans is not as detailed as that in some other surveys, so the entries in the right hand panel on the share of income from pensions should be viewed with caution. Chris Anguelov, Iams, and Purcell (2012) in particular raise concerns about the under-reporting 
of payouts from defined contribution pension plans. Individuals with assets in such plans, but who are not taking withdrawals in a given year, will not report any pension income. For those below the age of $701 / 2$, the age at which required minimum distributions from such plans begin, this could represent a large fraction of the account holders.

These concerns notwithstanding, for those in the top two quartiles of the income distribution pension income appears to be a substantial source of retirement support. It accounts for about one fifth of total income. About half of the individuals in this group report receiving pension income. For those in the quartile just above the median, Social Security benefits account for more than half of their income. Asset income of all kinds represents less than seven percent of total income. This does not imply that households have little financial wealth, since some might have assets such as bank deposits that yield very little income. The principal associated with these investments could nevertheless be used to support retirement spending. Resolving this issue requires balance sheet data.

The last column in Table 6 indicates that elderly individuals in the top quartile of the income distribution draw income from a range of sources, including all three components of the "three-legged stool" as well as earnings. Social Security benefits and pension income each account for about one fifth of the income of these individuals, while income from assets accounts for a bit less - about one sixth. Half of those in the top quartile report some earned income, and earnings account for more than 40 percent of the income for this group. The table shows a stark contrast between individuals in the top quartile of the distribution, and those below median income. Social Security is the predominant source of income for those in the lower two quartiles, which underscores the critical role of changes in Social Security benefits in affecting the well-being of these individuals.

Table 6 does not provide any information on age-related differences in the relative importance of various income streams, but they are substantial. The importance of earnings declines with increasing age. Roughly 37 percent of the "youngest elderly," those between the ages of 65 and 69, report some earnings. This declines to 21 percent for the 70-74 age group, and to only 7 percent for those over the age of 80 . At all ages, individuals who are still working are disproportionately likely to be in the upper income strata. For the 75+ group, for example, 27 percent of those in the top quartile report earned income, and income from earnings accounts for 
24 percent of their total income. Only 9.7 percent of the $75+$ group reported any earned income, so more than 60 percent of those with earnings were in the top income quartile.

Younger and married elderly individuals are more likely to be in the top quartile of the income distribution for all elderly individuals. In 2013, 34 percent of individuals aged 65-69 were in the top quartile of the income distribution for all 65+ individuals, compared with only 16.1 percent of those over the age of 80 . The oldest old are often in different financial circumstances than their younger counterparts, and they are more likely to depend on Social Security as their primary income source. Women account for 77 percent of the individuals in the lowest income quintile, and they are disproportionately the "oldest old."

The importance of earnings as a source of income for the elderly has changed substantially in the last four decades. Table 8 shows labor force participation rates for various

Table 8: Labor Force Participation Rates for Individuals Over the Age of 65, 1970-2010

\begin{tabular}{|l|l|l|l|l|}
\hline \multirow{2}{*}{ Year } & Men & $70+$ & Women & $70+$ \\
\cline { 2 - 5 } & $65-69$ & $17.6 \%$ & $65-69$ & $5.7 \%$ \\
\hline 1970 & $41.6 \%$ & 13.1 & $17.3 \%$ & 4.5 \\
\hline 1980 & 28.5 & 10.7 & 15.1 & 4.7 \\
\hline 1990 & 26.0 & 12.0 & 17.0 & 5.8 \\
\hline 2000 & 30.3 & 14.7 & 19.5 & 8.3 \\
\hline
\end{tabular}

Source: Federal Inter-agency Forum on Aging-Related Statistics (2012), Table 11.

sub-groups of the elderly since 1970. The data show that the labor force participation rate for men aged 65-69 and 70+ declined in the 1970s and 1980s, but has rebounded since then. The 2010 value is more than 1.5 times the postwar low for this participation rate for men, which occurred in 1985 (24.4 percent). The labor force participation rate for women over the age of 65 is higher today than in past decades, reflecting in part the rising labor force participation rate at younger ages and the persistence of labor market activity over the life course. Teresa Ghilarducci (2008) observes that in the last two decades, the rise in labor force participation rates at older ages has roughly kept pace with rising longevity, and that the rapid growth rate in the expected number of late-life years out of the labor force has ended. On average, someone who turned 65 in the 1970s would have many more years of retirement than someone born 30 years earlier, that is not the case for someone turning 65 in 2014. 
It is difficult to determine whether the rising labor force participation rate at older ages reflects increased notional supply of labor at older ages holding financial status constant, for example as a result of falling disability rates, or a reaction to changes in the level and structure of retirement income support, such as changes in the pension system or adverse financial shocks. It is most likely a combination, with some elderly individuals pushed to work longer by financial circumstances, while others choose to work longer because of the rising age of onset of activityrestricting disabilities. Survey evidence seems to support such a mixture. Ruth Helman, Nevin Adams, Craig Copeland, and Jack VanDerhei (2013) report that in the 2010 EBRI Retirement Confidence Survey, most "retirees" who were working for pay reported at least one positive reason for doing so, such as enjoying working (86 percent) and wanting to stay active (92 percent). The same survey, however, also found that at 90 percent of this group indicated that at least one financial reason contributed to their continued working.

Despite substantial changes in the private pension system in the last three decades, the share of the elderly reporting some pension income changed very little between 1988 (35 percent) and 2013 (33 percent). The most substantial change over this period was the growth in the importance of earnings individuals in the upper half of the income distribution; the relative importance of other income sources for elderly individuals has been relatively stable over time. In 1988, the first year when the March Current Population Survey could be used to make tabulations that are directly comparable to those for 2013, only 11.5 percent of the over-65 individuals in the top quartile of the income distribution reported any earnings. In 2013, the analogous value was 51.3 percent. Between 1988 and 2013, there was a modest decrease in the fraction of those over 65 reporting asset income: from 69 to 50 percent. One potential explanation of this shift is the rise of IRAs and 401(k)-type plans. The income earned on assets held in these accounts would be reported today as pension income. Before the rise of these accounts, the interest, dividends, and capital gains on retirement saving would have been reported as asset income.

IV. From Income to Wealth: Household Balance Sheets of the Elderly

Data on the sources of income for elderly individuals provides an important perspective on retirement security, but they do not reflect the depth of resources that these individuals might 
draw on in the event of financial need. For that purpose, it is necessary to consider balance sheet data. Since many assets are held jointly in married couples, it is also more natural to focus on households rather than individuals when considering balance sheet information.

Poterba, Venti, and Wise (2011a, 2013) show the distribution of wealth holdings for households aged 65-69 in the 2008 wave of the Health and Retirement Study. Table 9 summarizes this information. Most of the surveys were conducted before June 2008, so they can

Table 9: Distribution of Wealth Holdings for Households Aged 65-69, 2008

\begin{tabular}{|c|c|c|c|c|c|c|c|}
\hline Percentile & $\begin{array}{l}\text { Net } \\
\text { Worth }\end{array}$ & $\begin{array}{l}\text { Social } \\
\text { Security }\end{array}$ & $\begin{array}{l}\text { Defined } \\
\text { Benefit } \\
\text { Pension } \\
\text { Wealth }\end{array}$ & $\begin{array}{l}\text { Total Non- } \\
\text { Annuitized } \\
\text { Wealth }\end{array}$ & $\begin{array}{l}\text { Financial } \\
\text { Assets } \\
\text { Outside } \\
\text { Retirement } \\
\text { Accounts } \\
\end{array}$ & $\begin{array}{l}\text { Personal } \\
\text { Retirement } \\
\text { Account } \\
\text { Assets }\end{array}$ & $\begin{array}{l}\text { Housing } \\
\text { and } \\
\text { Other } \\
\text { Real } \\
\text { Estate } \\
\end{array}$ \\
\hline \multicolumn{8}{|c|}{ Panel A: All Households } \\
\hline 10 & $\$ 127.3$ & $\$ 0.0$ & $\$ 0.0$ & $\$ 0.1$ & $\$ 0.0$ & $\$ 0.0$ & $\$ 0.0$ \\
\hline 30 & 289.3 & 126.8 & 0.0 & 71.8 & 2.0 & 0.0 & 42.0 \\
\hline 50 & 548.2 & 187.4 & 0.0 & 221.7 & 15.0 & 5.0 & 120.0 \\
\hline 70 & 911.9 & 227.8 & 83.0 & 518.0 & 70.0 & 75.0 & 229.5 \\
\hline 90 & 1826.4 & 384.8 & 329.6 & 1274.0 & 358.0 & 347.0 & 585.0 \\
\hline \multicolumn{8}{|c|}{ Panel B: Married Households } \\
\hline 10 & 240.9 & 0.0 & 0.0 & 24.7 & 0.0 & 0.0 & 12.0 \\
\hline 30 & 509.2 & 195.3 & 0.0 & 158.0 & 6.0 & 0.0 & 90.0 \\
\hline 50 & 769.1 & 284.0 & 0.0 & 357.0 & 27.8 & 35.0 & 170.0 \\
\hline 70 & 1234.1 & 342.6 & 116.1 & 755.7 & 107.0 & 137.0 & 300.0 \\
\hline 90 & 2224.2 & 425.2 & 440.4 & 1677.8 & 459.2 & 464.0 & 725.0 \\
\hline
\end{tabular}

Source: Poterba, Venti, and Wise (2013).

be thought of as pre-financial crisis. The data underlying Table 9 do not reflect the sharp decline in equity values that took place in late 2008 and early 2009; they reflect some of the decline in house prices that had began in 2006 and 2007. The entries in each column are based on distributions constructed for the wealth component in that column. Thus the net worth of the household with the median value of net worth is $\$ 548,200$. When households are ranked by total financial assets held outside retirement accounts such as 401(k)s and IRAs - an asset category with many low values - the median household has just $\$ 15,000$. This value is larger $-\$ 27,800$ - for married households, but the table makes clear that financial assets for at least half of the distribution are modest and that the most important components of the balance sheet for those in 
the bottom half, and perhaps the bottom two thirds of the distribution, are the present discounted value of their Social Security wealth and their home equity. Because the table reports quantiles, and households are ranked separately for each column, it is not possible to add across the rows. Thus, while the household at the tenth percentile of the distribution of each distinct asset class may report zero holdings, the household in the tenth percentile when all the wealth components are aggregated can report a positive value.

The virtual absence of financial wealth and DB pension wealth for roughly half of the "young elderly" households in Table 9 is consistent with the information on income flows in Table 6, and in particular the central importance of Social Security income in the bottom half of the income distribution. The balance sheet data suggest that in addition to having low incomes, these households have very limited financial resources with which to absorb financial shocks. This situation, not surprisingly, persists at older ages, even though the households who live the longest are disproportionately drawn from the upper tier of the income and wealth distributions. Poterba, Venti, and Wise (2012) analyze wealth holdings in the last AHEAD survey that respondents completed before their death, which on average was carried out about one year before death. Among those who were single when they entered the survey in the mid-1990s, 57 percent had less than $\$ 10,000$ in combined retirement accounts and other financial assets when last surveyed. For those who were married when first surveyed, and who were the second-to-die in their couple, it was 46 percent. Even for those who were the first to die, the group that on average is best prepared for retirement, 32 percent had less than $\$ 10,000$. Fifty-two percent of this group had less than $\$ 50,000$.

Housing equity is a key component of the net worth of elderly households, and it is distributed more equally than many other assets. The role of housing equity in supporting retirement well-being has been an active subject of research, and tapping housing equity is a potentially important source of precautionary wealth for the elderly. Venti and Wise (2004) describe housing equity dynamics among elderly households. They find that most households do not draw down their housing equity, especially in their early retirement years. In a sample period that was characterized by generally rising house prices, they document a pattern of rising home equity for most households below the age of 75. They furthermore find that most declines in home equity are associated with shocks, such as the death of a spouse in a married couple, or a 
major illness. The decline in the average level of housing equity among households at older ages is primarily the result of large reductions for a small group of households.

Determining whether housing equity is comparable to other elements of the household balance sheet, because it can be drawn down in a financial emergency, is an important but still unresolved question. It is important for assessing retirement preparation. John Karl Scholz, Ananth Seshadri, and Surachai Khitatrakun (2006) find that the fraction of households approaching retirement who have accumulated the level of assets that would be implied by the solution to a stochastic dynamic lifecycle model depends on whether housing equity is or is not included in the lifecycle wealth aggregate. Purcell (2012) illustrates this point in his report of post-retirement income replacement rates in the Health and Retirement Study. For the initial cohort of HRS respondents who worked for at least three survey waves, he finds a median (25th percentile) replacement rate of $0.73(0.48)$ based only on household income. When he includes the annuitized value of non-housing assets, these values rise to 0.90 and 0.61 , respectively. Adding the annuity value of housing equity increases these values further, to 1.0 and 0.68 . Thus considering the annuity value of housing is important even in the lower strata of the retiree wealth distribution.

These studies are part of a large literature that attempts to judge the adequacy of retirement saving. Michael Hurd and Susann Rohwedder (2012), one of the most systematic recent studies of retirement saving adequacy, find that 71 percent of those aged 66-69 have resources that provide a 95 percent chance of dying with positive wealth. Alicia Munnell, Anthony Webb, and Francesca Golub-Sass (2012), who report on the "National Retirement Readiness Index," find a lower fraction well-prepared when they consider a broader, and younger, age group. While various studies employ different methodologies to assess retirement income preparedness, the finding that a significant group of households is not saving enough for retirement emerges in many studies.

How to construct a target replacement rate for pre-retirement income, and how it might vary across different strata of the income distribution, is an open research issue. Peter Brady (2010) provides a survey of a number of the key measurement issues that arise in computing replacement rates. These include determining how consumption needs change at retirement as a result of differential work-related expenses, recognizing the value of government-provided 
retiree health insurance (Medicare), and handling the potentially important role of changes in consumption needs over the life course that are associated with raising children. The balance sheet data in Table 9, for example, does not include the present discounted value of Medicare and Medicaid benefits. The income tabulations reported earlier similarly exclude any incomeequivalent value for these benefits.

Some studies have compared consumption outlays before and after retirement as a way of trying to identify households that, as a result of a drop in consumption, were worse off after retirement. Hurd and Rohwedder (2013) present a recent summary of the changes in consumption spending that occur at retirement. As in so many other aspects of retirement security, they find substantial heterogeneity. In the low-wealth population they find evidence of a post-retirement decline in consumption, on average, particularly for those who retire earlier than expected and as a result of health limitations. This drop in consumption may signal undersaving among this group. For some higher wealth households they find increases in consumption outlays.

Finding that some households have virtually no financial wealth as they approach retirement has often been interpreted as a challenge to the stochastic lifecycle hypothesis, and as a call for further study of the appropriate framework for analyzing saving decisions. In the presence of retirement pension programs such as Social Security, and with health insurance available through Medicare and Medicaid, since the presence of post-retirement transfer income and insurance programs such as Medicare and Medicaid may substantially reduce the need for private saving. Mariacristina Dinardi, Eric French, and John Jones (2010) model the stochastic properties of late-life medical expenditures and analyze optimal saving behavior in the presence of such expenses. They conclude that precautionary saving against out-of-pocket medical costs is a potentially critical driver of saving among higher-income households, while the presence of Medicaid for lower-income elderly can account for much lower stocks of financial assets among this group.

Late-life medical expenditures, in particular the possibility of out-of-pocket spending for higher income households, may help to explain another empirical regularity which seems to challenge the lifecycle model. This is the slow rate of draw-down of retirement wealth among those who accumulate it. Poterba, Venti, and Wise (2011b) report that for the median elderly 
household that does not experience a family status shock, such as the loss of a spouse in a married couple, net worth is stable or rising between the ages of 65 and 80 . Spending on medical care appears to be an important factor associated with the draw-down of retirement saving. James Smith (1999) summarizes a large literature on the interplay between health status and economic circumstances for older households, and Courtney Coile and Kevin Milligan (2009) provide evidence from the Health and Retirement Study suggesting that health shocks are associated with declines in asset holdings. Health needs are a particularly important source of end-of-life spending, which is why they figure prominently in many discussions of precautionary saving. Samuel Marshall, Kathleen McGarry, and Jonathan Skinner (2011) present information on out-of-pocket medical spending in only the last year of life. While the mean is modest $\$ 11,618$ - the 90 th percentile value is $\$ 49,907$, and the 99 th percentile is $\$ 94,310$. The interplay between uninsured late-life expenditures, of which medical costs not covered by Medicare or Medicaid probably loom largest for many households, and the trajectory of wealth in retirement is one of the most active research topics in the field of retirement saving.

\section{The Evolution of Employment-Related Retirement Saving Vehicles}

The data on retirement income and balance sheets for the elderly show that particularly for those in the upper half of the income and wealth distribution, saving through employmentrelated saving vehicles provides an important source of retirement income and the accumulation in these vehicles represent a substantial share of wealth. The U.S. income tax system allows deferral of income earned in various retirement saving accounts, lowering the tax burden on assets held in these accounts relative to those held in other ways. The structure of employmentrelated saving has changed shifted substantially in the last three decades, with defined contribution plans growing in importance and individuals bearing a larger share of the responsibility for determining their retirement security.

Individual Retirement Accounts (IRAs) and employer sponsored pension plans are two ways for individuals to save for retirement while receiving "consumption tax treatment" of their saving. This means that the interest, dividends, and capital gains on their accumulation in these accounts is not taxed on accrual, but upon withdrawal. This contrasts with "income tax treatment" which would tax these flows on accrual or, in the case of capital gains, on realization. 
Individuals can open "traditional" IRAs, as well as their "Roth IRA" counterparts, at various financial institutions, and they may contribute to them provided they have earned income. The contribution limit in 2014 for an IRA is $\$ 5500$ (\$6500 for those over 50) or total earnings, whichever is less. In a "traditional" IRA, the contribution to the account may be deducted from current taxable income, and the withdrawal is taxable as ordinary income. This means that one dollar invested today will yield $(1+r)^{T} *\left(1-\tau_{\mathrm{T}}\right)$, where $\tau_{\mathrm{T}}$ is the individual's tax rate at the time of withdrawal. For "Roth" IRAs, contributions are made net of tax, so if an individual devotes one dollar of earnings to a Roth IRA, the amount available after $\mathrm{T}$ years is $(1+r)^{\mathrm{T}} *\left(1-\tau_{0}\right)$, where $\tau_{0}$ is the individual's marginal tax rate at the time of contribution. Because the dollar limits for traditional and Roth IRAs are the same, but Roth contributions are net of tax, the amount of retirement income that can be purchased by the contribution of an amount, say $\$ 1000$, to a Roth IRA is greater than the amount of retirement income that can be purchased with an equivalent contribution to a traditional IRA. The individual's current income taxes would be higher, however, if the contribution were devoted to a Roth IRA, so the effective current cost of the Roth contribution is greater. IRAs can also receive contributions when individuals choose to withdraw assets from other pension plans, and in recent years such "rollover" contributions have been substantially larger than contributions from earned income.

Employer sponsored retirement plans include both defined benefit (DB) and defined contribution (DC) plans. DB plans, which expanded sharply in the United States after World War II, provide an annuitized stream of benefits once the individual reaches retirement age. They typically specify benefits as a function of past earnings, and in some cases they require employee contributions in addition to employer contributions. DB plans usually permit lump sum payouts when the employee changes jobs and at retirement. DC plans, of which 401(k) plans and 403(b) plans are the most common, allow individuals to contribute a fraction of their salary, often with an employer match, to an account that accumulates without any tax on investment returns until the time of withdrawal. Annual contributions to these plans are limited to $\$ 17,500$ in 2014, with a "catch up contribution" of an additional $\$ 5,500$ for those over 50 . Individuals fortunate enough to be able to contribute the limit amount to these plans over prolonged periods can accumulate substantial amounts of retirement wealth. 
In the past three decades, virtually no private employers have introduced new DB plans, and many employers with existing plans have capped or closed them. The DC pension structure has been criticized, for example by Ghilarducci (2008), for eroding retirement security. How can this charge be squared with the observation by Peter Brady, Kimberly Burham, and Sarah Holden (2012) that many DC plan participants have accumulated substantial balances, or the report by Holden, VanDerhei, Luis Alonso, and Steven Bass (2013) that the total value of assets held in 401(k) plans reached \$4 trillion in the third quarter of 2013? The answer, evidence from the foregoing table, is "heterogeneity." There are many individuals of working age who are not participating in these programs of saving enough in them to provide significant retirement support, but there are also some who are accumulating substantial balances that will help support post-retirement consumption.

To illustrate the changing nature of these programs, Table 10 presents information from Department of Labor surveys in 1985, 1990, and 2010 on pension coverage among different types of employers. In 1990, 59 percent of the employees at large and medium private

Table 10: The Changing Composition of Retirement Saving Plans, 1985-2010

\begin{tabular}{|l|l|l|l|l|l|l|}
\hline & \multicolumn{2}{|l|}{ Any Plan } & DB Plan & DC Plan \\
\hline & $1990(1985)$ & 2010 & $1990(1985)$ & 2010 & $1990(1985)$ & 2010 \\
\hline $\begin{array}{l}\text { Medium \& } \\
\text { Large Private } \\
\text { Establishments }\end{array}$ & $78 \%(91 \%)$ & $66 \%$ & $59 \%(80 \%)$ & $30 \%$ & $48 \%(41 \%)$ & $54 \%$ \\
\hline $\begin{array}{l}\text { Small Private } \\
\text { Establishments }\end{array}$ & 42 & 35 & 20 & 9 & 31 & 31 \\
\hline $\begin{array}{l}\text { State \& Local } \\
\text { Governments }\end{array}$ & 96 & 94 & 90 & 87 & 9 & 19 \\
\hline
\end{tabular}

Source: EBRI (2013), Chapters 4 and 10. The "1990" data for medium and large private establishments corresponds to the 1991 survey of this group.

establishments were covered by DB plans. In 2010, only 30 percent were. The U.S. Department of Labor (2001) estimates that in 1979, 10 percent of private sector wage and salary workers were covered by a DB and a DC plan, while another 28 percent had only a DB plan and 7 percent had only DC plan coverage. These statistics yield a total of 45 percent with pension coverage of some type. By 1998, 15 percent had both DB and DC, 7 percent had only a DB, while the percentage with only a DC had increased to 27 percent. A total of 49 percent of 
workers had pension coverage of some type. Recent tabulations by the Bureau of Labor Statistics (2013) based on the March 2013 National Compensation Survey suggest that that 49 percent of private sector workers have some form of pension coverage, with 9 percent covered by both DB and DC, another 7 percent by just DB, and 33 percent by just DC. The data on DB plans may overstate the extent to which workers are currently accruing DB plan benefits, since 26 percent of private sector workers who participate in DB plans are in "frozen" plans that no longer accrue benefits for participants and no longer accept new members. To understand the implications of these statistics for retirement income support, it is important, as some of the foregoing studies of replacement rates do, to examine whether those without employer pension coverage have substantial replacement rates from other sources, such as Social Security.

Table 10 also shows that the dramatic shift in private sector pension plans has not been mirrored in public sector plans. In 1990, 90 percent of state and local government employees were estimated to participate in a DB plan; in 2010 that number was 87 percent. Munnell, Kelly Haverstick, and Mauricio Soto (2007) offer a number of potential explanations for the relative persistence of DB plans in the public but not the private sector, including differential sensitivity of taxpayers and stock market investors to the cost and volatility of these plans.

To place the pension coverage data in Table 10 in context, recall the foregoing discussion of the changes over time in the fraction of individuals over the age of 65 who report receiving pension income. Even when the penetration of DB plans was close to its peak, in the late 1970s and early 1980s, only about 50 percent of private sector workers participated in pension plans. The shift from DB to DC plans in the private sector has not had dramatic effects on the extent of pension plan participation, but it has changed the set of retirement-related risks facing individuals. In a DB plan, the greatest risks are that workers will separate from their employer before they reach the late-career stage at which pension wealth accumulates most rapidly. In a DC plan, eligible employees must make many decisions about their retirement saving, and there are consequently many ways to deliberately or inadvertently avoid accumulating substantial retirement balances.

Table 11 places the ownership of IRAs, 401(k)s and other DC plans, as well as DB plans, in perspective, drawing upon data from the 2010 Survey of Consumer Finances (SCF). Munnell (2012) reports similar findings with respect to $401(\mathrm{k}) \mathrm{s}$ from the same data set. The table reports 
data for households, but it also distinguishes single individuals. Account balances are typically higher for households than for individuals, because some households have two members with DC plans or IRAs. In addition, data on household balances will show much larger values than data on 401(k) or other DC plan accounts, for example as reported by firms that record-keep for such plans, because an individual may have multiple DC accounts as a result of having worked for multiple employers.

Table 11 reports entries for four age groups, each spanning ten years, beginning with those 45-54. In each case the age of the household is defined as the age of the household head. The entries in the first two columns indicate whether the household owns the given type of retirement account, while the next six columns are related to the value of these accounts. The table illustrates the expansion of both DC plan participation and IRAs. The entries in Panels A and B show that the probability of having an IRA rises with age, while the probability of having a DC plan falls. Married households headed by someone between the ages of 55 and 64, for example, are about 15 percentage points more likely to have an IRA than married households ten years younger. This in part reflects the fact that IRAs are often funded with roll-over contributions from employer-provided DC and, in some cases, DB plans. In contrast, among 6574 year old married households, 21 percent report having a DC plan; for those 45-64, the probability is 54 percent. The diffusion of $401(\mathrm{k})$ plans has been well documented using a variety of data sets. Poterba, Venti, and Wise (2011c), for example, use SIPP data and find patterns very similar to those reported in Table 10. Married households are substantially more likely to report both DC plans and IRAs than are their single counterparts. 
Table 11: Household Ownership of Retirement Accounts and Pension Plans, 2010

\begin{tabular}{|c|c|c|c|c|c|c|c|c|}
\hline & \multicolumn{2}{|c|}{$\begin{array}{l}\text { Account Value }> \\
0\end{array}$} & \multicolumn{2}{|c|}{$\begin{array}{l}\text { Account Value > } \\
\$ 50 \mathrm{~K}\end{array}$} & \multicolumn{2}{|c|}{$\begin{array}{l}\text { Account Value }> \\
\$ 100 \mathrm{~K}\end{array}$} & \multicolumn{2}{|c|}{$\begin{array}{l}\text { Mean (Median) Balance } \\
\text { Conditional on }>0\end{array}$} \\
\hline & Single & Married & Single & Married & Single & Married & Single & Married \\
\hline \multicolumn{9}{|c|}{ Panel A: IRA } \\
\hline $45-54$ & $19.2 \%$ & $34.2 \%$ & 6.5 & 17.7 & 3.3 & 12.4 & $\begin{array}{l}\$ 65,177 \\
(\$ 21,000)\end{array}$ & $\begin{array}{l}\$ 145,491 \\
(\$ 54,000)\end{array}$ \\
\hline $55-64$ & 30.4 & 48.7 & 12.6 & 29.2 & 7.8 & 23.2 & $\begin{array}{l}99,794 \\
(34,000)\end{array}$ & $\begin{array}{l}211,105 \\
(90,000)\end{array}$ \\
\hline $65-74$ & 25.4 & 50.6 & 13.4 & 35.8 & 9.2 & 26.7 & $\begin{array}{l}236,412 \\
(53,000)\end{array}$ & $\begin{array}{l}282,943 \\
(113,000)\end{array}$ \\
\hline $75+$ & 21.9 & 43.7 & 12.6 & 24.5 & 8.0 & 16.2 & $\begin{array}{l}138,006 \\
(55,000)\end{array}$ & $\begin{array}{l}157,414 \\
(53,000)\end{array}$ \\
\hline \multicolumn{9}{|c|}{ Panel B: Defined Contribution (DC) Pension } \\
\hline $45-54$ & 29.5 & 53.7 & 10.7 & 32.9 & 5.7 & 23.6 & $\begin{array}{l}71,376 \\
(25,000)\end{array}$ & $\begin{array}{l}159,758 \\
(70,000)\end{array}$ \\
\hline $55-64$ & 22.0 & 44.9 & 8.2 & 31.8 & 5.4 & 24.6 & $\begin{array}{l}103,065 \\
(28,100)\end{array}$ & $\begin{array}{l}283,461 \\
(100,000)\end{array}$ \\
\hline $65-74$ & 7.3 & 21.2 & 2.9 & 15.1 & 1.9 & 11.8 & $\begin{array}{l}86,283 \\
(26,000)\end{array}$ & $\begin{array}{l}257,243 \\
(86,000)\end{array}$ \\
\hline $75-84$ & 3.1 & 7.6 & 1.2 & 3.4 & 0.6 & 2.9 & $\begin{array}{l}122,638 \\
(30,000)\end{array}$ & $\begin{array}{l}283,451 \\
(36,000)\end{array}$ \\
\hline \multicolumn{9}{|c|}{ Panel C: IRA or DC Pension or Both } \\
\hline $45-54$ & 43.2 & 68.2 & 16.1 & 43.0 & 9.0 & 31.0 & $\begin{array}{l}82,181 \\
(29,000)\end{array}$ & $\begin{array}{l}203,051 \\
(80,000)\end{array}$ \\
\hline $55-64$ & 43.5 & 69.8 & 20.1 & 48.5 & 12.7 & 41.1 & $\begin{array}{l}128,023 \\
(45,000)\end{array}$ & $\begin{array}{l}338,030 \\
(130,000)\end{array}$ \\
\hline $65-74$ & 31.8 & 61.6 & 15.8 & 43.4 & 11.1 & 34.2 & $\begin{array}{l}215,681 \\
(49,000)\end{array}$ & $\begin{array}{l}333,434 \\
(138,000)\end{array}$ \\
\hline $75-84$ & 24.4 & 47.7 & 14.1 & 26.1 & 8.6 & 18.2 & $\begin{array}{l}145,673 \\
(65,000)\end{array}$ & $\begin{array}{l}206,947 \\
(57,600)\end{array}$ \\
\hline \multicolumn{9}{|c|}{ Panel D: Defined Benefit (DB) Pension } \\
\hline $45-54$ & 17.7 & 25.6 & 16.1 & 26.6 & 13.4 & 22.4 & $\begin{array}{l}277,102 \\
(181,674)\end{array}$ & $\begin{array}{l}343,449 \\
(193,564)\end{array}$ \\
\hline $55-64$ & 25.1 & 40.7 & 23.0 & 36.9 & 19.9 & 33.2 & $\begin{array}{l}323,697 \\
(225,932)\end{array}$ & $\begin{array}{l}388,783 \\
(267,577)\end{array}$ \\
\hline $65-74$ & 41.5 & 49.7 & 29.4 & 43.5 & 22.3 & 39.4 & $\begin{array}{l}167,939 \\
(124,967)\end{array}$ & $\begin{array}{l}403,121 \\
(274,918)\end{array}$ \\
\hline $75-84$ & 53.1 & 62.1 & 26.2 & 50.5 & 17.4 & 37.1 & $\begin{array}{l}122,662 \\
(85,102)\end{array}$ & $\begin{array}{l}195,777 \\
(123,749)\end{array}$ \\
\hline
\end{tabular}

Source: Author's tabulations using 2010 Survey of Consumer Finances.

Table 11 also illustrates two other features of the current retirement saving system. First, roughly two thirds of households approaching retirement age, those in the 55-64 age group, have 
either a DC plan or an IRA or both. Second, even though many households have these accounts, a substantial share have accumulated relatively little in them, and they are unlikely to be able to support a significant flow of retirement consumption with their account balance. The four columns in the middle of Table 11 illustrate this. The data in Panel $\mathrm{C}$ show that while 62 percent of married households in the 65-74 age group, and 32 percent of singles, report having an IRA or a DC plan account, only 34 percent of married households and 11 percent of singles have accumulated more than $\$ 100,000$, combined, in these accounts. There is substantial dispersion in plan balances: the mean balance for married households in this age group, $\$ 333,434$, is more than 2.5 times the median $(\$ 138,000)$. The pattern is similar for those in the $55-64$ year old age group. While 70 percent of the married households report having at least one IRA or DC plan account, only 41 percent have more than $\$ 100,000$ in combined account values.

Table 11 also presents information on the coverage of DB plans, and estimates of the expected present discounted value (EPDV) of the associated benefits. The first two rows in Panel D show that 41 percent of married households aged 55-64, and 50 percent of those 65-74, report some DB plan coverage. The fraction of households with DB plans declines to 26 percent for those aged 45-54.

The EPDV estimates shown in the last two columns, which are described in more detail in the appendix, are subject to substantial uncertainty particularly for the age 45-54 and 55-64 age groups because for these groups it is usually necessary to rely on self-reported estimates of the amount of prospective pension payouts and the date at which such payouts will begin. The EPDV estimates suggest that for households that are now in their late 60s and early 70s, the mean value of prospective DB payouts, for those with DB plans, is comparable to the mean value of DC plan and IRA accumulations, but the median value of the DB payouts is substantially higher. The pattern is somewhat different for 55-64 year olds. For married households in this age group, the conditional means are again comparable, but for single persons, the conditional mean for the DB plans is substantially greater than that for the combination of DC plans and IRAs. These patterns suggest that the dispersion in the combined value of IRAs and DC plans is somewhat greater than the dispersion of in the EPDV of DB plans for those with each type of pension coverage. 
The finding that for a significant group of households approaching retirement, the amount accumulated in DC plans and IRAs falls short of the EPDV of the DB plans of older cohorts is an essential part of understanding the shifting nature of retirement preparation. Barbara Butrica, Iams, Karen Smith, and Toder (2009) simulate the effect of freezing existing private sector DB plans and replacing them with DC plans. They conclude that such changes would generate a distribution of outcomes, with some prospective retirees receiving higher retirement income and others less. The number of future retirees who would receive less income is projected to exceed the number who would receive more, and those receiving less would be concentrated among younger cohorts with relatively little accumulation in the existing DB plans.

The shifting pattern of retirement plan coverage over the last three decades can be illustrated by tracking households in the same birth cohort using the synthetic cohorts associated with repeated Survey of Consumer Finances. Table 12 applies this approach with the 1992, 2001, and 2010 surveys. The age ranges are nine years wide, which prevents overlap across the various intervals. Reading across the table shows retirement plan participation for a given birth cohort as it ages; reading "up" the table shows the age-specific changes for successively younger cohorts within a survey wave. The first row, for example, shows the percentage of households headed by someone born between 1936 and 1944 that reported participating in a DC plan in each of the three surveys. These percentages are stable in 1989 (33.9 percent), when these household heads were between 48 and 56 years old, and 2001 (33.7 percent, when the household heads were 57 to 65 years old), but decline to 18 percent in 2010, when the household heads were between the ages of 66 and 74. The table shows that the age-specific rate of DC plan coverage rises over time for nearly all age groups. For DB plans, the table shows the sharp decline in coverage. For those between the ages of 38 and 55, the decline in the age-specific rate of DB plan coverage was approximately 20 percentage points over the 18 year sample period. 
Table 12: Repeated Cross-Section Evidence on Retirement Plan Participation, 1989-2010

\begin{tabular}{|c|c|c|c|}
\hline \multirow[t]{2}{*}{ Birth Cohort } & \multicolumn{3}{|c|}{ SCF Date } \\
\hline & 1992 & 2001 & 2010 \\
\hline \multicolumn{4}{|c|}{ Panel A: DC Plan } \\
\hline 1936-1944 & 0.339 & 0.337 & 0.182 \\
\hline 1945-1953 & 0.331 & 0.458 & 0.365 \\
\hline 1954-1962 & 0.265 & 0.494 & 0.464 \\
\hline 1963-1971 & 0.174 & 0.457 & 0.456 \\
\hline \multicolumn{4}{|c|}{ Panel B; DB Plan } \\
\hline 1936-1944 & 0.503 & 0.466 & 0.439 \\
\hline 1945-1953 & 0.433 & 0.395 & 0.395 \\
\hline 1954-1962 & 0.317 & 0.287 & 0.301 \\
\hline 1963-1971 & 0.187 & 0.199 & 0.217 \\
\hline \multicolumn{4}{|c|}{ Panel C: Any Retirement Account (DB, DC, or IRA) } \\
\hline 1936-1944 & 0.705 & 0.766 & 0.661 \\
\hline $1945-1953$ & 0.677 & 0.736 & 0.709 \\
\hline $1954-1962$ & 0.563 & 0.701 & 0.683 \\
\hline 1963-1971 & 0.337 & 0.622 & 0.617 \\
\hline
\end{tabular}

Source: Author's tabulations from 2010 Survey of Consumer Finances.

The entries down the diagonal in Table 12, those in bold, track the age-specific rate of pension participation. Thus in the second panel, in 1992, 50.3 percent of households headed by someone between the ages of 48 and 56 reported DB plan coverage. By twelve years later, the percentage of those between 48 and 56 with DB pension coverage was 39.5 percent, and nine years later still, it was 30.1 percent for those in this same age group. The last panel shows that the age-specific rates of any retirement plan participation, combining IRAs, 401(k)s, other DC plans, and DB plans, was relatively stable over this 1989-2010 period.

Table 11 demonstrates the heterogeneity in the retirement saving plan participation of U.S. households approaching, and in, retirement. Some have no formal saving program at all; some have only a DC or a DB plan; some have a DB plan, a DC plan, and also have accumulated assets in an IRA. Whether participation in different types of plans is complementary, or whether participation in one plan substitutes for participation in another, is a key empirical issue. If the various retirement saving vehicles are substitutes, then those with small balances in one saving vehicle may have offsetting balances in other accounts. Table 13 shows the coverage of various 
Table13: Overlap in Retirement Saving Vehicles, Households Aged 55-64, 2010

\begin{tabular}{|l|l|l|l|l|}
\hline & Percentage of Households & \multicolumn{4}{l|}{ Median Balances (000s) } \\
\cline { 2 - 5 } & \multicolumn{5}{|l|}{ DC } & DB & IRA \\
\hline Panel A: One Retirement Plan Only & $12.8 \%$ & $\$ 29$ & & \\
\hline DC Plan & 12.8 & & 234 & \\
\hline DB Plan & 11.8 & & & 46 \\
\hline IRA & 7.6 & 45 & 192 & \\
\hline Panel B; Two Retirement Plans & 154 & & 68 \\
\hline DC \& DB & 9.1 & \multicolumn{5}{|l|}{} \\
\hline DC \& IRA & 9.5 & 288 & 53 \\
\hline IRA \& DB & 10.0 & 98 & 307 & 79 \\
\hline Panel C: Three Retirement Plans & \multicolumn{5}{|l|}{} \\
\hline IRA, DB, \& DC & 10.0 &
\end{tabular}

Source: Author's tabulations from 2010 Survey of Consumer Finances.

retirement plans and the balances in these plans for households headed by individuals aged 55 to 64 in 2010. The table focuses on the 73.6 percent of the respondents in this age group who report some type of retirement saving plan. Among those with some retirement saving plan, 37.4 percent report only one saving plan; they are in the first panel. At the other extreme, 10 percent of households report that they have a DB plan, a DC plan, and an IRA. Another 26.2 percent of households report two of these three types of plans. The data do not suggest substitution. For those with all three types of saving plans, median IRA balances and the median EPDV of their DB plans is greater than for any of the other groups of households. The households that report only one type of plan have smaller median balances than those with multiple plans. This pattern further suggests heterogeneity of the type discussed above; some households are not only have DB plans but are also participating in other retirement saving plans. Some but not all of this heterogeneity is income related; Venti and Wise (2001) document wide variation in retirement saving propensities throughout the income distribution.

Before concluding the discussion of the shift from DB to DC plans, it is important to recognize the range of choices that DC plans permit individuals to make, and the role that these choices play in determining retirement security. DB plans provide participants with relatively few choices, other than whether to continue working for the firm that provides the pension plan, and when to retire conditional on continued employment. These decisions can have a very important effect on the value of retirement payouts in DB plans. In contrast, individuals who 
work for firms that offer DC plans can choose whether or not to participate in the plan, how much to contribute, how to allocate their accumulated assets, whether (in many plans) to borrow against their accumulated balance, whether, if they change jobs, to withdraw their balance as a lump sum distribution, how quickly to draw down their assets in retirement, and whether to purchase an annuity or to pursue another strategy for withdrawing assets. All of these decisions are consequential, and they create multiple decision points at which an individual might make a decision that could enhance or impair his retirement security. Critics of the DC structure, such as Ghilarducci (2008), point out that many individuals fail to accumulate substantial retirement resources because of choices that they make at various decision nodes. Poterba, Joshua Rauh, Venti, and Wise (2007) examine the relative riskiness of accumulating retirement benefits in private-sector DB and DC plans, and underscore that participants face risk in both. One of the challenges of a retirement system based on a DC structure is providing individuals with enough information and training to make responsible decisions regarding whatever choices they are provided.

In the last fifteen years, changes in the regulatory and legislative environment surrounding DC plans have allowed some firms that offer 401(k) plans to adopt a more "defaultoriented" model that utilizes automatic enrollment when employees join the firm and relies on default asset allocations. Mitchell and Stephen Utkus (2012) estimate that about one fifth of the plan participants in their sample of 401(k) plans managed by Vanguard were enrolled in plans that featured automatic enrollment. Close to 60 percent of the new hires at firms in their sample were auto-enrolled. Firms confront a difficult problem in this setting when they must choose plan defaults. Most 401(k) plan default contribution rates are below the rates that participants would need to save at in order to accumulate retirement resources that could replace a significant fraction of their pre-retirement income. Vanguard (2013) reports that a contribution rate of 3 percent is the predominant default rate. Moreover, the choice of a default can affect the active decisions of plan participants. Gabriel Carroll, James Choi, Laibson, Brigitte Madrian, and Andrew Metrick (2009) examine these issues and begin to develop a theory of optimal default design.

The empirical evidence on participant behavior in DC plans provides further support for the theme of household heterogeneity. While some individuals make choices that may place 
their retirement security in jeopardy, aggregate statistics suggest that many plan participants make decisions that seem broadly consistent with the recommendations of many financial advisers. At the end of 2012, for example, VanDerhei, Holden, Alonso, and Bass (2013) estimate 61 percent of 401(k) assets were invested in stocks, while 33 percent were invested in bonds or similar fixed-income investments. Older participants have less stock exposure than their younger counterparts. The share of $401(\mathrm{k})$ assets invested in company stock, an investment choice that increases a household's exposure to the fortunes of a firm with which it already has an employment relationship, was 7 percent. Company stock allocations in 401(k) plans have fallen by more than half since 1999, before the collapse of Enron, a firm at which many employees had invested their 401(k) plan assets in company stock. Loans outstanding represented 13 percent of current 401(k) balances.

Some assets are withdrawn from the 401(k) system before retirement. Matt Fellowes and Katy Willemin (2013) highlight these pre-retirement outflows, which weaken retirement security. Among those near retirement, withdrawals are relatively low. Poterba, Venti, and Wise (2011c) report that the annual average rate of withdrawal from personal retirement accounts, a combination of IRAs and 401(k)s, for households headed by someone in their 60s is about 2 percent; this rises to close to 6 percent after the account-holding individuals pass the age of 70 1/2, when required minimum distributions come into play.

One of the most important decisions that DC plan participants must make is how much to contribute to their plan. Barbara Butrica and Karen Smith (2012) report a median contribution rate, based on SIPP data, of 5.0 percent in 2010, with a range from 4.7 to 5.2 between 1990 and 2010. In 2010, as in earlier years, there is an upward slope in the age-contribution percentage profile. Median contribution rates rise from 3.1 percent for those in their 20s to 6.3 percent for those between the ages of 60 and 64. These contribution amounts reflect only employee contributions. Since many employers provide a substantial matching contribution when employees contribute - 50 percent is a common value - the share of salary being contributed to $401(\mathrm{k})$ plans is larger than 5 percent. 
VI. Retirement Saving in a Low-Return Environment

The capacity of an individual saver to accumulate wealth for retirement, whether through an employer sponsored DC plan, an IRA, or through saving outside such plans, is a function of the rate of return that accumulating assets can earn and the horizon over which the assets are invested. Accumulating retirement wealth and drawing income from a stock of assets once accumulated are both more challenging in a period of low expected returns. A decline in prospective returns, like the one that has occurred in bond markets during the last six years, affects those who are saving for retirement as well as those who are at or near retirement, because the income that their accumulated assets can generate may fall below their preretirement expectations. This section explores the effect of changes in expected returns on the saving rates needed to accumulate a given level of retirement resources.

The riskless real returns available to savers have varied substantially during the last decade. The Federal Reserve Bank of St. Louis FRED database reports that the real yield on newly-issued 20-year Treasury Inflation Protected Securities (TIPS) declined from an average of 2.18 percent in the last six months of 2004, when these bonds were first available, to 0.75 percent in 2013. Over this period the highest average yield was 2.36 percent in 2007; the 2012 average value, 0.22 percent, was the lowest, and there were some months in 2012 when the yield was negative. While the 20-year TIPS data series only begins in 2004, a few years earlier investors could obtain even higher long-term inflation-protected real returns. In November, 2000, for example, a newly-issued federal I-bond, an inflation-protected savings bond, offered a real return of 3.4 percent.

The decline in real riskless yields in the last decade makes it more difficult for a saver to reach a wealth target at a fixed retirement age. Consider the accumulated retirement wealth that a saver will accumulate, as a share of final earnings, from saving one percent of earnings each year for $\mathrm{T}$ years. The calculations assume that real earnings rise one percent each year. If earnings at the start of the saving plan are normalized to 1.0, final earnings are therefore $\mathrm{w}(\mathrm{T})=$ $(1.01)^{\mathrm{T}}$. The value in period $\mathrm{T}$ of one percent of salary, saved in period $\mathrm{s} \leq \mathrm{T}$, is

$$
\mathrm{V}(\mathrm{s}, \mathrm{T})=.01 *(1.01)^{\mathrm{s} *}(1+\mathrm{r})^{(\mathrm{T}-\mathrm{s})} \text {. }
$$

The total value of retirement saving over a $T$ period career, $R(T)$, is then

$$
\mathrm{R}(\mathrm{T})=\Sigma_{\mathrm{s}=0, \mathrm{~T}-1} \cdot 01^{*}(1.01)^{\mathrm{S} *}(1+\mathrm{r})^{(\mathrm{T}-\mathrm{s})} \text {. }
$$


Table 14 reports the value of wealth at retirement scaled by final earnings, $R(T) / W(T)$. The table considers careers lasting 20,30, and 40 years, and real rates of return between 1 and 4

Table 14: Wealth-to-Earnings Ratio at Retirement from 1\% Annual Saving

\begin{tabular}{|l|l|l|l|l|}
\hline Years of Saving & $\mathrm{r}=0.04$ & $\mathrm{r}=0.03$ & $\mathrm{r}=0.02$ & $\mathrm{r}=0.01$ \\
\hline 20 & 0.28 & 0.26 & 0.22 & 0.20 \\
\hline 30 & 0.49 & 0.41 & 0.35 & 0.30 \\
\hline 40 & 0.77 & 0.61 & 0.49 & 0.40 \\
\hline
\end{tabular}

Source: Author's calculations.

percent per year. The table shows that when the real return is 2 percent and the length of a working career is 40 years, saving 1 percent of earnings each year leads to a wealth stock at retirement equal to 0.49 times final earnings. Saving 5 percent of earnings each year for 40 years would result in a retirement wealth-to-income ratio of $2.45\left(=5^{*} 0.49\right)$. If the real interest rate is 2 percent per year, shifting the saving horizon from 40 to 20 years reduces the wealth-to-earnings ratio per percentage point of saving from 0.49 to 0.22 , a decline of more than 50 percent. Raising the rate of return from 2 percent per year to 4 percent per year has a pronounced effect when the saving horizon is long. For the 20 year saving horizon, it increases the incremental wealth-to-income ratio from 0.22 to 0.27 , but for the 40 year horizon, from 0.49 to 0.77 .

The calculations in Table 14 suggest that someone who saves 6 percent of her salary starting at age 35, and who retires at age 65, will accumulate a stock of retirement assets equal to 2.1 times her final wage if the real return is 2 percent, and 2.94 times her final wage if the real return is 4 percent. This underscores the importance of starting early to accumulate retirement wealth, as well as the challenge that a low-return environment poses for retirement savers.

The discussion of retirement saving in previous sections focused on the value of assets in IRAs and DC plans for various cohorts, highlighting the low accumulations in many of these accounts. For those who have accumulated substantial assets, however, it is natural to ask what fraction of final salary can be replaced by an annuity purchased at retirement. There is a large literature on the demand for annuities, and the extent to which annuities should feature in an optimal retirement plan. Jeffrey Brown (2011) provides an introduction. To convert a wealth stock into an annuity for individuals or married couples, one needs data on the annuity stream that can be purchased per dollar of wealth at retirement. If a(T) denotes the annual annuity 
payment for an annuity purchased in year $\mathrm{T}$, then an individual's earnings replacement rate in period $\mathrm{T}$ is $\mathrm{a}(\mathrm{T}) * \mathrm{R}(\mathrm{T}) / \mathrm{W}(\mathrm{T})$.

Table 15 reports the payout rate in October 2013 for an annuity on the life of a 65-year old man, a 65-year-old woman, and for a married couple (65 year old man with a 60 year old spouse) purchasing a second-to-die annuity with full payments continuing for the surviving spouse. The payouts on a range of annuity products offered by different insurance companies are reported each quarter in the Annuity Shopper. The table shows the average value across all the policies presented in the October 2013 issue. For example, the average annual payout for the annuities offering joint and survivor protection for a 65-year-old husband and 60-year-old wife, and costing $\$ 100,000$, was $\$ 5364$ per year, or 0.054 times the premium value. All of the annuities provide monthly payouts; the table shows the simple sum of the twelve monthly payouts as a share of the purchase price. The table shows that annuity payouts for men are

Table15: Annual Payouts Per Dollar of Annuity Premium, October 2013

\begin{tabular}{|l|l|l|l|}
\hline & Life Annuity & $\begin{array}{l}\text { Life Annuity with 3\% } \\
\text { Annual Escalation }\end{array}$ & $\begin{array}{l}\text { Life Annuity with } \\
\text { 20 Years Certain }\end{array}$ \\
\hline Male, Age 65 & 0.069 & 0.051 & 0.060 \\
\hline Female, Age 65 & 0.064 & 0.047 & 0.058 \\
\hline $\begin{array}{l}\text { Joint \& Survivor, Male 65 and } \\
\begin{array}{l}\text { Female 60, 100\% Survivor } \\
\text { Income }\end{array}\end{array}$ & 0.054 & 0.037 & 0.053 \\
\hline $\begin{array}{l}\text { Joint \& Survivor, Male 70 and } \\
\text { Female 65, 100\% Survivor } \\
\text { Income }\end{array}$ & 0.059 & 0.043 & 0.057 \\
\hline
\end{tabular}

Source: Annuity Shopper (2013).

higher than those for women on account of the higher mortality rate for men, and that the payouts are substantially lower when the annuity contract promises a 3 percent annual increase. For all three annuity contracts - those for men, women, and couples — selecting the 3 percent escalation provision reduces the initial payout by 26 percent.

The information in Table 15 can be combined with the wealth-to-earnings calculations in Table 14 to illustrate the annuity replacement rate that will be generated by a given saving strategy over the course of an individual's career. For example, if the long-term real rate of return is 2 percent, then the replacement rate that will result from saving one percent of salary 
each year over a 40 year career is the entry in Table 14 for $r=0.02$ and $T=40,0.49$, times the annuity payout rate from Table 15. The latter value is 0.069 for the nominal annuity and 0.051 for the 3 percent indexed annuity. These values are respectively 0.034 and 0.025 . Thus if the goal is to save enough to purchase an annuity that will replace half of one's earnings at retirement, the required saving rate is 14.8 percent of salary $(=0.50 / 0.034)$ for the nominal annuity and 20 percent of salary $(=0.50 / 0.025)$ for the 3 percent increasing annuity. If the saving horizon is just ten years shorter — 30 years — the required saving rate is substantially higher in both cases.

It is important to note that the Annuity Shopper data from October 2013 correspond to a month when the yield on 20-year TIPS was 1.05 percent, so the data on annuity payouts in Table 15 are best paired with low rate of return assumptions in the accumulation phase. In an environment with higher safe real interest rates, such as the 4 percent considered in Table 14, the annual payouts on annuities like those in Table 15 that cost $\$ 100,000$ would likely be greater than the observed market payouts in late 2013.

Table 16 reports required saving rates to replace half of earnings at retirement for various permutations of career lengths, rates of return, and annuity choice. The calculations

Table 16: Annual Saving Rate Required to Support Annuity Stream Equal to Half of Final Earnings at 65

\begin{tabular}{|l|l|l|l|l|l|}
\hline \multirow{2}{*}{$\begin{array}{l}\text { Career } \\
n\end{array}$} & Real Return & Men & \multicolumn{2}{l|}{ Women } \\
\cline { 3 - 6 } & & $\begin{array}{l}\text { Nominal } \\
\text { Annuity }\end{array}$ & $\begin{array}{l}\text { 3\% } \\
\text { Increasing } \\
\text { Annuity }\end{array}$ & $\begin{array}{l}\text { Nominal } \\
\text { Annuity }\end{array}$ & $\begin{array}{l}\text { 3\% Increasing } \\
\text { Annuity }\end{array}$ \\
\hline 20 & .02 & $32.7 \%$ & $44.3 \%$ & $35.3 \%$ & 48.2 \\
\hline 30 & .02 & 20.7 & 28.1 & 22.4 & 30.5 \\
\hline 40 & .02 & 14.8 & 20.0 & 15.9 & 21.7 \\
\hline 20 & .03 & 27.7 & 37.5 & 29.9 & 40.8 \\
\hline 30 & .03 & 17.6 & 23.9 & 19.0 & 26.0 \\
\hline 40 & .03 & 11.9 & 16.1 & 12.8 & 17.5 \\
\hline 20 & .04 & 26.4 & 35.7 & 28.4 & 38.8 \\
\hline 30 & .04 & 14.9 & 20.2 & 16.1 & 22.0 \\
\hline 40 & .04 & 9.4 & 12.8 & 10.2 & 13.9 \\
\hline
\end{tabular}

Source: Author's calculations. 
suggest that saving rates like the median 401(k) contribution rate are unlikely to enable prospective retirees to replace half of their final earnings. This finding must be viewed against the backdrop of the earlier evidence on Social Security replacement rates. For those in the lower strata of the income distribution, even low replacement rates from saving through DC plans or IRAs may yield total replacement rates that permit post-retirement consumption at a level not far below the household's pre-retirement level.

The calculations in Tables 14 and 16 assume that investors earn riskless returns, when in fact most DC plan and IRA assets are invested in assets with uncertain real returns. Addressing the risks associated with accumulating assets for retirement, and then converting them into income streams, is a key aspect of retirement planning. Raising the riskiness of the assets held in a retirement portfolio can offer the prospect of higher expected returns, but at the price of greater dispersion in the range of retirement wealth values. The discussion of the effect of real interest rates on annuity payouts highlights another important risk which has not received as much attention as accumulation risk: annuitization risk. In 1993, when the average yield on AAA corporate bonds was 7.9 percent, the annual payout per dollar of annuity premium for a singlepremium immediate annuity purchased by a 65-year-old male was 9.7 percent. Twelve years later, in 2005, when the AAA rate was 5.4 percent, the annuity payout was 7.8 percent. In 2013, when the AAA rate averaged 3.8 percent, the annuity payout was 6.3 percent. An individual who had been accumulating resources with the goal of financing a specific retirement income target would have needed 24 percent more wealth in 2013 than in 2005 to meet this goal. Robert Merton (2012) argues that retirement planning should focus on generating a consumption stream in retirement, not a stock of wealth at the date of retirement, since it is consumption that ultimately determines well-being. While capital risk, the risk to principal, in retirement accumulation is widely discussed, Merton draws attention to income risk, the risk to the household's feasible stream of income in retirement, and suggests a variety of strategies for hedging this risk. This is an ongoing topic of research at the intersection financial economics and financial planning. 
VII. Raising Saving Rates: Insights from Behavioral Economics

The data on retirement saving by the cohort of households now approaching retirement suggests that a significant subset may need to raise their saving rate if they hope to avoid a decline in consumption after retirement. Their plight is likely to be worse if financial markets deliver returns that are below their historical averages for a substantial part of the next decade. These observations lead naturally to the question of whether there are public or private policies that might raise private saving. While historically public policy has focused on tax incentives such as the "consumption tax" treatment of IRA and pension accumulations as a means to encourage retirement saving, these approaches have recently been complemented by insights from behavioral economics.

One reason behavioral approaches may be helpful is that many households have on limited financial literacy. Annamaria Lusardi and Mitchell (2014) present the findings of a "financial literacy module" of the Health and Retirement Study. Respondents were asked three questions: (i) If $\$ 100$ earns 2\% per year for 5 years, how much will you have in the account? (more than $\$ 102$, exactly $\$ 102$, less than $\$ 102$ ); (ii) If the interest rate on your savings account is 1 percent per year, and inflation is 2 percent, in a year, can you buy more, the same, or less in a year?; and (iii) "Buying a single company stock usually provides a safer return than a stock of a mutual fund. True or False?" The probabilities that respondents answered these questions correctly were 67, 75, and 52 percent, respectively; only 34 percent answered all three correctly. The power of compound interest and incentives based on prospective rates of return may have limited influence for those without a rudimentary command of the mechanics of saving.

A substantial body of work over the last fifteen years has explored strategies for raising saving that do not rely on rice incentives, such as the creative use of defaults in corporate 401(k) plans. Madrian and Dennis Shea (2001) were one of the first to document that the saving behavior of a substantial fraction of newly-hired employees is affected by default provisions in DC plans. James Choi, Laibson, Madrian, and Andrew Metrick (2004) study the experience of a number of companies that switched from a voluntary 401(k) plan to an "opt-out" structure. They find sharp increases in 401(k) participation rates for each of the firms they study. David Card and Michael Ransom (2011) find that individuals do not regard personal and employer contributions to retirement saving plans as perfect substitutes, and that they save more when the 
employee contribution is low than when it is high, even if this is fully offset by variation in employer contributions.

Recent evidence on the saving behavior of Danish households further supports the importance of default provisions. Raj Chetty, John Friedman, Soren Leth-Petersen, Torben Nielsen, and Tore Olsen (2013) find that when employer contributions to retirement saving arrangements change, up to 85 percent of the affected individuals make no change in their personal saving plans, even though by making such changes they could hold constant their total, employer plus employee, saving rate. They describe the group that does not respond as "passive savers," and suggest that for this group, public and private initiatives that rely on individuals taking action may have relatively little effect on saving behavior.

Shlomo Benartzi and Richard Thaler (2013) present a strategy for increasing retirement saving that focuses on expanding eligibility for employment based saving plans, and then relying on automatic enrollment, automatic asset allocation rules, and automatic escalation of the fraction of salary that is contributed to the plan to help accumulate retirement wealth. The evidence that automatic enrollment can increase contributions to DC plans for some employees who might not otherwise save through this channel partly explains the recent growth of various default-oriented plans that was noted above.

Observing that many households do not understand key principles of retirement saving and do not respond when the saving environment changes does not imply that price-based saving incentives cannot raise saving and retirement preparedness. These incentives may not work, however, for households in this group. A key research issue that bears on policy design is the extent of overlap between the set of households that are price-sensitive with regard to retirement saving and the set of households that are on a trajectory that will result in too little retirement saving to sustain their pre-retirement living standard in retirement.

\section{Conclusion}

Declining old-age mortality has important consequences for individual lifecycle planning and for aggregate economic analysis. For individuals, it implies a need to plan for potentially longer retirement spans, or longer working lives, and to adjust saving plans accordingly. For the U.S. economy at large, it implies rising fiscal burdens as a result of a rising share of the 
population receiving benefits from Social Security, Medicare, and Medicaid, and a decline in number of individuals who are working relative to the number in the population. An aging population may also be associated with a declining rate of innovation.

There is widespread variation in the sources of income support for the elderly population in the U.S. Individuals who are over 65 whose incomes fall below the median rely disproportionally on Social Security for retirement income. Those in the top quartile display a more varied mix of income sources, with earnings, pension income, and income from assets all making significant contributions to their support. The importance of Social Security for those in the lower income range implies that changes in the benefits associated with this program, for this group, would be likely to translate directly into living standards.

The structure of private-sector retirement arrangements has undergone substantial change in the last three decades. Many defined benefit pension plans for existing employees in the private sector have been capped or frozen, and new employees and those at new firms are much more likely to be covered by defined contribution plans than by defined benefit plans. In the public sector, in contrast, defined benefit plans remain prevalent. Defined contribution plans place more responsibilities for securing an adequate retirement income on individuals, who can choose whether to participate in their retirement plan, how much to contribute, how to invest, and how and when to draw down the assets they have accumulated. The multiplicity of decision nodes in the defined contribution system places a greater reliance on building financial literacy, and on using the insights from behavioral economics to support future retirement security, than the defined benefit system did.

Retirement saving is affected by many public policies: Social Security, Medicare, and Medicaid; the eligibility rules for a range of other transfer programs; the tax rules and other regulations affecting pension plans; and the wide array of regulatory and other policies that affect the behavior of financial institutions that supply retirement saving products. Designing public policy toward retirement security must recognize both the heterogeneity among households saving for retirement, as well as the multiple policy objectives that are served by various policy instruments.

In thinking about retirement security, it may be helpful to focus on three distinct groups: those in lower income strata who are likely to find it difficult to engage in private saving, and for 
whom Social Security is the primary source of retirement income; those at moderate incomes, for whom expanding access to retirement saving vehicles and encouraging saving through those vehicles could raise retirement preparedness; and those at the highest income levels, for whom the private sector defined contribution structure provides a range of opportunities for saving. The study of pension policy by Nicholas Barr and Peter Diamond (2008) illustrates the many tradeoffs that policy-makers must confront in designing both public retirement support programs and the retirement saving structures that complement them, and illustrates these tradeoffs with a range of country studies.

One of the consequences of the aging U.S. population that can be predicted with near certainty is the continuing demand for analysis of the economic effects of this demographic shift.

\section{Appendix:}

\section{Computing the Expected Present Discounted Value of DB Payouts for SCF Respondents}

To compare the value of DC plan accumulations with the value of prospective payments in DB plans, it is necessary to construct the expected present discounted value (EPDV) of future DB payouts. For households in the SCF that report current income from DB plans, this involves projecting the current benefit flow forward, recognizing the prospective mortality experience of the beneficiary and the possibility of survivor benefits in married couples, and then constructing the EPDV. The DB payouts are always assumed to take the form of an annuity. If an SCF respondent reports that his DB payments are protected by a cost of living adjustment (COLA), the current payment is discounted at the real interest rate and the age-specific mortality rates that apply to the respondent. The real interest rate is defined as the annual average yield for 2010 on long-term AAA bonds, 4.94 percent (as reported in Table H.15 of Board of Governors of the Federal Reserve System (2013)), minus the expected ten-year inflation rate for the year 2010 as reported by the Livingston Survey that is carried out by the Federal Reserve Bank of Philadelphia (2013). If the participant reports that the benefits are not COLA-protected, the reported payout is discounted at the nominal interest rate. If the respondent does not report whether the benefits are inflation-protected, the benefits are assumed to grow at 0.4 times the expected inflation rate each year, and the resulting benefit stream is discounted at the AAA rate. 
Mortality is projected using the cohort life tables from Bell and Miller (2005). If the respondent is married and reports that pension benefits will continue after the primary beneficiary's death, the spouse is assumed to receive the full value of the pension if he or she outlives the primary beneficiary. If there is no information on spousal benefits, a surviving spouse is assumed to receive a 50 percent continuing payout.

For SCF respondents who are currently working and who report that they will receive DB benefits when they retire from their current job, we assume that retirement will occur at age 65. When the benefits are specified as a fraction of final salary, nominal earnings are assumed to rise by 3 percent per year until age 58, then by 1 percent per year until 65; Card and Ransom (2011) make a similar assumption about the wage trajectory.

A number of previous studies have attempted to estimate the value of prospective DB plan payouts, and it is helpful to place the entries in Panel D of Table 11 in context. Alan Gustman, Thomas Steinmeier, and Nahid Tabatabai (GST) (2012) use data from the Health and Retirement Study to compute household balance sheets in 2006 and 2010. For households that had DB pensions in both years, they estimate the average 2010 value of a DB pension to be $\$ 314,000$, compared with an average value of $\$ 162,000$ for DC plans conditional on having a plan. For those with IRAs, the average value in 2010 was $\$ 216,000$, again conditional on a positive value. The entries in Table 11 are broadly consistent with GST's (2012) estimates for DB plans, but the value of DC holdings in Table 11 exceeds their HRS-based estimates. This pattern has been noted before; Venti (2012) discusses a number of reasons for under-reporting of DC plan balances in the HRS.

Gale and Pence (2006) present estimates of DB wealth in both the HRS and the SCF for 1992. They focus on households that were headed by someone aged 51 to 61 in 1992, and report average DB wealth across all households of $\$ 95,808$ for the SCF and $\$ 106,041$ for the HRS, again suggesting that the two surveys yield similar results. Edward Wolff (2011) calculates DB pension wealth in multiple waves of the SCF between 1983 and 2007. His estimate of average DB wealth for households over the age of 65 in 2007 is $\$ 91,200$, which seems somewhat lower than the value that would be implied by the EPDV estimates in Table 11. Importantly, he also presents Gini coefficients for both DB wealth and the balances in DC plans, and reports less dispersion for DB plans. Poterba, Venti, and Wise (2013) calculate mean holdings of IRAs and 
DC plans of $\$ 121,137$ for $65-69$ year-old households in the HRS in 2008, and $\$ 99,147$ for the EPDV of DB pension benefits for this group. Within this age group, 52 percent report ownership of a DC plan or an IRA, and 42 percent report having a DB plan. 


\section{References}

Agarwal, Sumit, John C. Driscoll, Xavier Gabaix, and David Laibson. 2009. "The Age of Reason: Financial Decisions Over the Life Cycle and Implications for Regulation." Brookings Papers on Economic Activity, Fall 2009, 51-117.

Anguelov, Chris E., Howard M. Iams, and Patrick J. Purcell. 2012. "Shifting Income Sources of the Aged." Social Security Bulletin 72 (3): 59-68.

Annuity Shopper. 2013. 28(3). Englishtown, NJ: Annuity Shopper. Accessed on December 15, 2013 at http://www.immediateannuities.com/pdfs/as/annuity-shopper-currentissue.pdf?arx $=\mathrm{d}$.

Arnott, Robert D. and Denis B. Chaves. 2012. "Demographic Changes, Financial Markets, and the Economy." Financial Analysts Journal. 68 (1): 23-46.

Barr, Nicholas and Peter Diamond. 2008. Reforming Pensions: Principles and Policy Choices. Oxford: Oxford University Press.

Bell, Felicitie C. and Michael L. Miller. 2005. "Life Tables for the United States Social Security Area 1900-2100." U.S. Social Security Administration, Actuarial Study 120.

Benartzi, Shlomo and Richard Thaler. 2013. "Behavioral Economics and the Retirement Saving Crisis." Science 339 (March 8): 1152-1153.

Bloom, David, and Alfonso Sousa-Poza. 2013. "Aging and Productivity: Introduction." Labour Economics. 22: 1-4.

Board of Governors of the Federal Reserve System. 2013. Economic Research and Data: Selected Interest Rates, H.15. Available at http://www.federalreserve.gov/econresdata/statisticsdata.htm.

Board of Trustees, Federal Old-Age and Survivors Insurance and Federal Disability Trust Funds. 2013. 2013 Annual Report of the Board of Trustees of the Federal Old-Age and Survivors Insurance and Disability Insurance Trust Funds. Washington: U.S. Social Security Administration.

Börsch-Supan, Axel. 2013. "Myths, Scientific Evidence, and Economic Policy in an Aging World." Journal of the Economics of Ageing. 1: 3-15. 
Börsch-Supan, Axel, Alexander Ludwig, and Joachim Winter. 2006. "Ageing, Pension Reform, and Capital Flows: A Multi-Country Simulation Model." Economica 73 (292): 625-658.

Börsch-Supan, Axel, and Matthias Weiss. 2013. "Productivity and Age: Evidence from Work Teams at the Assembly Line." Working Paper RM/13/029, Maastricht University School of Business and Economics.

Brady, Peter. 2010. "Measuring Retirement Resource Adequacy." Pension Economics and Finance 9 (2): 235-262.

Brady, Peter, Kimberly Burham, and Sarah Holden. 2012. The Success of the U.S. Retirement System. Washington: Investment Company Institute.

Brown, Jeffrey R. 2011. "Rational and Behavioral Perspectives on the Role of Annuities in Retirement Planning." Journal of Pension Economics and Finance 10 (2): 315-336.

Butrica, Barbara A., Howard M. Iams, Karen E. Smith, and Eric J. Toder. 2009. "The Disappearing Defined Benefit Pension and Its Potential Impact on the Retirement Income of Baby Boomers." Social Security Bulletin 69 (3), 1-27.

Butrica, Barbara A. and Karen E. Smith. 2012. "401(k) Participant Behavior in a Volatile Economy." Working Paper 2012-24. Boston College: Center for Retirement Research.

Bureau of Labor Statistics, U.S. Department of Labor. 2013. Employee Benefits Survey. On the internet at http://www.bls.gov/ncs/ebs/benefits/2013/benefits_retirement.htm. Accessed December 29, 2013.

Card, David and Michael Ransom. 2009. "Pension Plan Characteristics and Framing Effects in Employee Savings Behavior." Review of Economics and Statistics 93 (1), 228-243.

Carroll, Gabriel D., James J. Choi, David Laibson, Brigitte C. Madrian, and Andrew Metrick. 2009. "Optimal Defaults and Active Decisions." Quarterly Journal of Economics, 124(4), 1639-1674.

Casanova, María. 2013. "Revisiting the Hump-Shaped Wage Profile." Mimeo, UCLA Department of Economics, Los Angeles, CA. Accessed January 182014 at http://www.econ.ucla.edu/casanova/Files/Casanova_wage_older_workers.pdf

Chetty, Raj, John Friedman, Soren Leth-Petersen, Torben Nielsen, and Tore Olsen. 2013. "Active vs. Passive Decisions and Crowd out in Retirement Saving Accounts: Evidence from Denmark." NBER Working Paper 18565. Cambridge: NBER. 
Choi, James J., David Laibson, Brigitte C. Madrian, and Andrew Metrick. 2004. "For Better or For Worse: Default effects and 401(k) Savings Behavior." In Perspectives on the Economics of Aging, ed. David Wise. Chicago: University of Chicago Press, 81-125.

Coile, Courtney and Kevin Milligan. 2009. "How Household Portfolios Evolve After Retirement: The Effects of Aging and Health Shocks." Review of Income and Wealth 55(2): 226-248.

Congressional Budget Office. 2013. The Distribution of Federal Spending and Taxes in 2006. Washington: Congressional Budget Office.

Cutler, David, Kaushik Ghosh, and Mary Beth Landrum. 2014. "Evidence for Significant Compression of Morbidity in the Elderly U.S. Population." In D. Wise, ed., Discoveries in the Economics of Aging. Chicago: University of Chicago Press.

Cutler, David, James Poterba, Louise Sheiner, and Lawrence Summers. 1990. "An Aging Society: Challenge or Opportunity?" Brookings Papers on Economic Activity, 1990(1): 174.

Day, Jennifer Cheeseman. 1996. Population Projections of the United States by Age, Sex, Race, and Hispanic Origin: 1995 to 2050. U.S. Bureau of the Census, Current Population Reports, P25-1130. Washington: U.S. Government Printing Office.

DeNardi, Mariacristina, Eric French, and John B. Jones. 2010. "Why Do the Elderly Save? The Role of Medical Expenses." Journal of Political Economy 118 (1): 39-75.

Eggleston, Karen N. and Victor Fuchs. 2012. "The New Demographic Transition: Most Gains in Life Expectancy Now Realized Late in Life." Journal of Economic Perspectives 26(3), 137-156.

Employee Benefits Research Institute. 2013. EBRI Databook on Employee Benefits. Washington: EBRI.

Federal Reserve Bank of Philadelphia. 2013. Historical Data: Livingston Survey: Mean Data. Accessed at http://www.phil.frb.org/research-and-data/real-time-center/livingston-survey/ Federal Interagency Forum on Aging-Related Statistics. 2012. Older Americans 2012: Key Indicators of Well-Being. Federal Interagency Forum on Aging-Related Statistics. Washington, DC: U.S. Government Printing Office. 
Fellowes, Matt and Katy Willemin. 2013. The Retirement Breach in Defined Contribution Plans: Size, Causes, and Solutions. Washington, DC: HelloWallet.

Gale, William G. and Karen M. Pence. 2006. "Are Successive Generations Getting Wealthier, and if so, Why? Evidence from the 1990s." Brookings Papers on Economic Activity 2006:1, 155-213.

Ghilarducci, Teresa. 2008. When I'm Sixty-Four: The Plot Against Pensions and the Plan to Save Them. Princeton: Princeton University Press.

Goldman, Dana, and Peter Orszag. 2014. "The Growing Gap in Life Expectancy: Using the Future Economic Model to Estimate Implications for Social Security and Medicare." American Economic Review: Papers and Proceedings 104.

Gustman, Alan L., Thomas L. Steinmeier, and Nahid Tabatabai. 2012. "How Did the Recession of 2007-2009 Affect the Wealth and Retirement of the Near Retirement Age Population in the Health and Retirement Study?" Social Security Bulletin 72 (4): 47-66.

Hacker, J. David. 2010. "Decennial Life Tables for the White Population of the United States, 1790-1900." Historical Methods: A Journal of Quantitative and Interdisciplinary History 43 (2): 45-79.

Helman, Ruth, Nevin Adams, Craig Copeland, and Jack VanDerhei. 2013. "The 2013 Retirement Confidence Survey: Perceived Savings Needs Outpace Reality for Many." EBRI Issue Brief Number 384. Washington: Employee Benefits Research Institute.

Hobbs, Frank and Nicole Stoops. 2002. Demographic Trends in the 20th Century. U.S. Census Bureau: CENSR-4. Washington: U.S. Government Printing Office.

Holden, Sarah, Jack VanDerhei, Luis Alonso, and Steven Bass. 2013. "401(k) Plan Asset Allocation, Account Balances, and Loan Activity in 2012." ICI Research Perspective 19 (12). Washington: Investment Company Institute.

Hurd, Michael and Susann Rohwedder. 2012. "Economic Preparation for Retirement." In Investigations in the Economics of Aging, ed. David Wise, 77-113. Chicago: University of Chicago Press.

Hurd, Michael and Susann Rohwedder. 2013. "Heterogeneity in Spending Change at Retirement." Journal of the Economics of Aging 1: 60-71. 
Iams, Howard and Patrick Purcell. 2013. "Social Security Income Measurement in Two Surveys." Social Security Bulletin 73 (3), 1-10.

Johnson, Richard and David Neumark. 1996. "Wage Declines Among Older Men." Review of Economics and Statistics. 78: 740-748.

Jones, Benjamin, E. J. Reedy, and Bruce A. Weinberg. 2014. "Age and Scientific Genius." In The Wiley Handbook of Genius, ed. D. K. Simonton. Oxford: John Wiley \& Sons.

King, Miriam, Steven Ruggles, J. Trent Alexander, Sarah Flood, Katie Genadek, Matthew B. Schroeder, Brandon Trampe, and Rebecca Vick. 2013. Integrated Public Use Microdata Series, Current Population Survey: Version 3.0. [Machine-readable database]. Minneapolis: University of Minnesota.

Lee, Ronald, Gretchen Donehower, and Tim Miller. 2011. NTA Country Report: US 2003. National Transfer Accounts Project: http://www.ntaccounts.org.

Liang, James, Hui Wang, and Edward Lazear. 2013. "Demographics and Entrepreneurship." Mimeo, Guanghua School of Management, Peking University.

Liu, Zheng and Mark Spiegel. 2011. "Boomer Retirement: Headwinds for U.S. Equity Markets." Federal Reserve Bank of San Francisco Economic Letter. 2011-26, August 22.

Lusardi, Annamaria and Olivia S. Mitchell. 2014. "The Economic Importance of Financial Literacy: Theory and Evidence." Journal of Economic Literature.

Madrian, Brigitte and Dennis Shea. 2001. "The Power of Suggestion: Inertia in 401(k) Participation and Savings Behavior." Quarterly Journal of Economics 116(4): 11491187.

Marshall, Samuel, Kathleen McGarry, and Jonathan Skinner. 2011. "The Risk of Out-of-Pocket Health Care Expenditure at the End of Life." In Explorations in the Economics of Aging, ed. David Wise, 101-128. Chicago: University of Chicago Press.

McGrattan, Ellen and Edward Prescott. 2013. "On Financing Retirement with an Aging Population." Federal Reserve Bank of Minneapolis Staff Report 472.

Mather, Mark. 2012. "Fact Sheet: The Decline in U.S. Fertility." Population Reference Bureau, World Population Data Sheet 2012. 
http://www.prb.org/Publications/Datasheets/2012/world-population-data-sheet/fact-sheetus-population.aspx

Meara, Ellen, Seth Richards, and David Cutler. 2008. "The Gap Gets Bigger: Changes in Mortality and Life Expectancy, by Education, 1981-2000." Health Affairs, 27(2): 350360.

Merton, Robert C. 2012. "Observations on Financial Education and Consumer Financial Protection." In Life-Cycle Investing: Financial Education and Consumer Protection, ed. Zvi Bodie, Laurence Siegel, and Lisa Stanton. Charlottesville, VA: Research Foundation of CFA Institute, 1-20.

Mitchell, Olivia S. and John W. R. Phillips. 2006. "Social Security Replacement Rates for Alternative Earnings Benchmarks." Benefits Quarterly Fourth Quarter: 37-47.

Mitchell, Olivia S. and Stephen Utkus. 2012. "Target Date Funds in 401(k) Retirement Plans." NBER Working Paper 17911. Cambridge, MA.

Munnell, Alicia. 2012, 401(k) Plans in 2010: An Update from the SCF. Boston College: Center for Retirement Research, Issue Brief 12-13.

Munnell, Alicia, Kelly Haverstick, and Mauricio Soto. 2007. Why Have Defined Benefit Plans Survived in the Public Sector? Boston College: Center for Retirement Research, Issue Brief.

Munnell, Alicia, Anthony Webb, and Francesca Golub-Sass. 2012. The National Retirement Risk Index: An Update. Boston College: Center for Retirement Research, Issue Brief 1220.

Murphy, Kevin M. and Finis Welch. 1990. "Empirical Age-Earnings Profiles." Journal of Labor Economics 8 (2): 202-229.

National Research Council. 2010. Choosing the Nation's Fiscal Future. Washington: National Academies Press.

National Research Council. 2012. Aging and the Macroeconomy: Long-Term Implications of an Older Population. Washington: National Academies Press.

Pijoan-Mas, Josep and José-Víctor Ríos-Rull. 2013. "Heterogeneity in Expected Longevities." Mimeo, University of Minnesota. 
Poterba, James. 2001. "Demographic Structure and Asset Returns." Review of Economics and Statistics 83(4): 565-584.

Poterba, James, Joshua Rauh, Steven Venti, and David Wise. 2007. "Defined Contribution Plans, Defined Benefit Plans, and the Accumulation of Retirement Wealth." Journal of Public Economics 91: 2062-2086.

Poterba, James, Steven Venti, and David Wise. 2011a. "The Composition and Draw Down of Wealth in Retirement." Journal of Economic Perspectives, 25 (4): 95-118.

Poterba, James, Steven Venti, and David Wise. 2011b. "Family Status Transitions, Latent Health, and the Post-Retirement Evolution of Assets." In Explorations in the Economics of Aging, ed. David Wise, 23-69. Chicago: University of Chicago Press.

Poterba, James, Steven Venti, and David Wise. 2011c. "The Drawdown of Personal Retirement Assets." NBER Working Paper 16675.

Poterba, James, Steven Venti, and David Wise. 2012. "Were They Prepared for Retirement? Financial Status at Advanced Ages in the HRS and the AHEAD Cohorts." In Investigations in the Economics of Aging, ed. David Wise, 21-69. Chicago: University of Chicago Press.

Poterba, James, Steven Venti, and David Wise. 2013. "Erratum.” Journal of Economic Perspectives, 27 (4): 219-222.

Poterba, James, Steven Venti, and David Wise. 2014. "Health, Education, and the PostRetirement Evaluation of Household Assets." Journal of Human Capital.

Purcell, Patrick J.. 2009. "Income of Americans Aged 65 and Older, 1968 to 2008." Washington: Congressional Research Service.

Purcell, Patrick J. 2012. "Income Replacement Ratios in the Health and Retirement Study." Social Security Bulletin 72 (3): 37-58.

Rogers, Diane Lim, Eric Toder, and Landon Jones. 2000. Economic Consequences of an Aging Population. Washington: Urban Institute.

Scholz, John Karl, Ananth Seshadri, and Surachai Khitatrakun. 2006. "Are Americans Saving 'Optimally' for Retirement?" Journal of Political Economy 114 (4), 607-643.

Sheiner, Louise. 2014. "Growth and Aging." American Economic Review: Papers and Proceedings. 104(4). 
Shoven, John B. and Sita N. Slavov. 2013. "Efficient Retirement Design: Combining Private Assets and Social Security to Maximize Retirement Resources." Working paper, Stanford Institute for Economic Policy Research.

Smith, James P. 1999. "Healthy Bodies and Thick Wallets: The Dual Relation Between Health and Economic Status." Journal of Economic Perspectives 13 (2): 145-166.

U.S. Census Bureau, Population Division. 2012. Percent Distribution of the Projected Population by Selected Age Groups and Sex for the United States, 2015 to 2060 (NP2012-T3). Washington.

U.S. Census Bureau, Current Population Survey, 2013 Annual Social and Economic Supplement. 2013. Available at http://www.census.gov/hhes/families/data/cps2013A.html (accessed 12/21/13).

U.S. Department of Labor, Pensions and Welfare Benefits Administration. 2001. Abstract of 1998 Form 5500 Annual Reports, Private Pension Plan Bulletin No. 11. Washington, DC.

U.S. Government Accountability Office. 2006. Baby Boom Generation: Retirement of baby Boomers is Unlikely to Precipitate Dramatic Decline in Market Returns, but Broader Risks Threaten Retirement Security. GAO Report 06-718. Washington.

Vanguard. 2013. How America Saves: A Report on Vanguard 2012 Defined Contribution Plan Data. Valley Forge, PA: Vanguard Institutional Investor Group.

VanDerhei, Jack, Sarah Holden, Luis Alonso, and Steve Bass. 2013. 401(k) Plan Asset Allocation, Account Balances, and Loan Activity in 2012. EBRI Issue Brief No. 394. Washington: Employee Benefits Research Institute.

Venti, Steven. 2011. "Economic Measurement in the Health and Retirement Study." Forum for Health Economics and Policy 14 (3).

Venti, Steve and David Wise. 2001. "Choice, Chance, and Wealth Dispersion at Retirement." In Aging Issues in the United States and Japan, ed. Seirtsu Ogura, Toshiaki Tachibanaki, and David Wise. Chicago: University of Chicago Press, 25-64.

Venti, Steven and David Wise. 2004. "Aging and Housing Equity: Another Look." In Perspectives on the Economics of Aging, ed. David Wise. Chicago: University of Chicago Press, 127-175. 
Waldron, Hilary. 2007. "Trends in Mortality Differentials and Life Expectancy for Male Social Security-Covered Workers, by Socioeconomic Status." Social Security Bulletin. 67(3), $1-19$.

Wolff, Edward N. 2011. The Transformation of the American Pension System: Was It Beneficial for Workers? Kalamazoo, MI: The Upjohn Institute. 